\title{
Research Paper \\ Evaluating the Future of Employment and Unemployment, With an Approach to General Policies of Employment
}

\author{
*Hassan Daliri
}

1. Assistant Professor of Economics, Department of Management and Economics, Faculty of Humanities and Social Science, Golestan University, Gorgan, Iran.

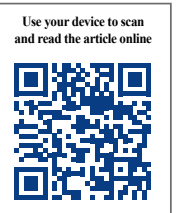

dration: Daliri H. (2019). [Evaluating the Future of Employment and Unemployment, with an Approach to General Policies of Employment (Persian)]. Quarterly Journal of the Macro and Strategic Policies, 7(3), 346-371. https://doi.org/10.32598/JMSP.7.3.2

https://doi.org/10.32598/JMSP.7.3.2

Received: 25 Nov 2017

Accepted: 04 Aug 2018

Available Online: 01 Oct 2019

Key words:

Golestan province, Unemployment rate, Future research

\begin{abstract}
A B STRACT
Considering the importance of unemployment in the context of resistive economics, the present study has tried to predict the future of this influential variable for Golestan Province using future research method. For this purpose, the present study was designed to simulate 11 scenarios for demand and 3 scenarios for labor supply, and a total of 33 different scenarios for unemployment and employment rates for women and men in the province. Finally, according to the experts, the probability of the scenarios was assessed and the most probable scenario for unemployment rate in Golestan province was identified. According to the results of the study, in 2027 the unemployment rate would be $19.4 \%$ for men and $25.9 \%$ for women, and unemployment rate of the province would be $20.5 \%$. On the other hand, Golestan province must create 7965 net annual jobs in order to remain in its current state of unemployment (2015 unemployment rate) in the period 2018-2027. Therefore, to overcome this challenge and turn it into an opportunity for growth and development, it is essential that provincial planners design a targeted structure for the province's labor market management.
\end{abstract}

* Corresponding Author:

Hassan Daliri, PhD.

Address: Department of Management and Economics, Faculty of Humanities and Social Science, Golestan University, Gorgan, Iran.

Tel: +98 (38) 737070

E-mail: h.daliri@gu.ac.ir 


\section{آيندهيثوهى اشتغال و بيكارى با رويكرد سياستهاى كلى اشتغال \\ •حسن دليرى}

1. استاديار اقتصاد، كروه مديريث، اقتصاد وحسابدارى، دانشكده علوم انسانى، دانشكّاه كلستان، كر كان، ايران.

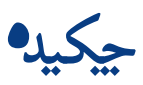

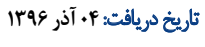

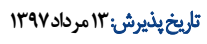

تاريخ انتشار:9 مهر 149

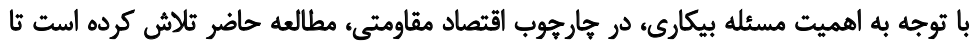

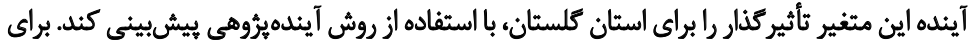

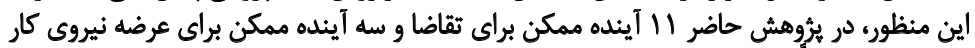

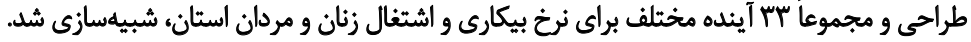

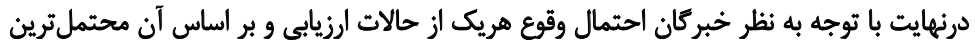

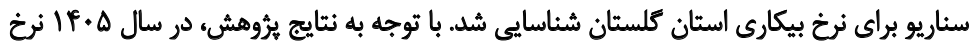

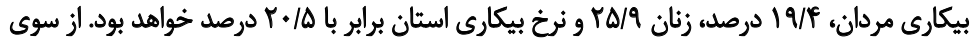

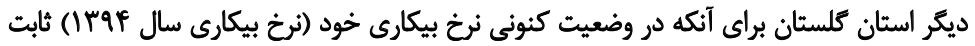

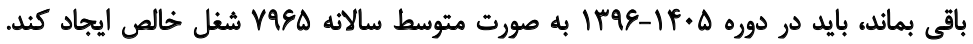

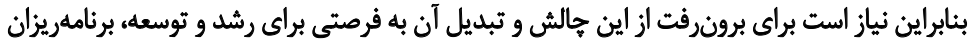

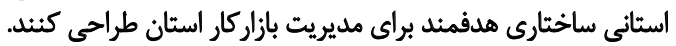

: So

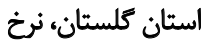

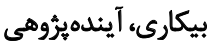




\section{مقدمه}

يكى از ممهمترين اهداف اقتصاد مقاومتى مقابله با شوكهاى درونى و بيرونى اقتصاد است، به گونهاى كه كشور

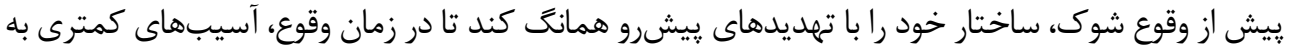

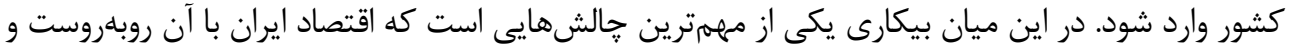

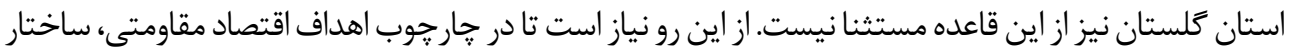

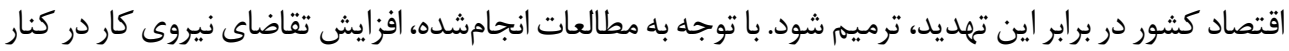

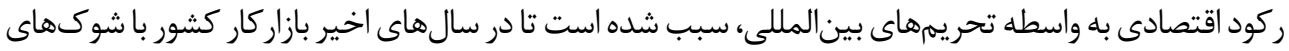

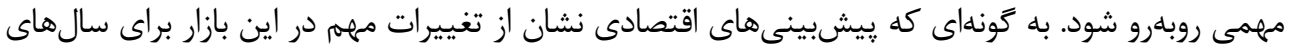

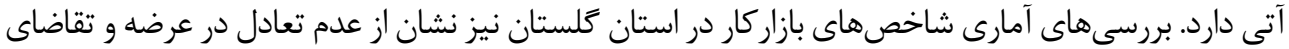

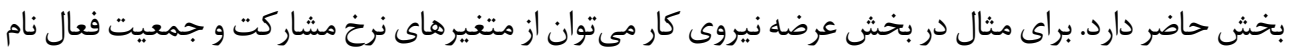

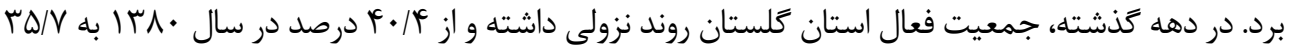
درصد در سال سوسا رسيده است.

آمارها نشان از آن دارد كه جمعيت فعال مردان تقريباً جهار برابر زنان بوده است كه با توجه به سهمه جمعيتى

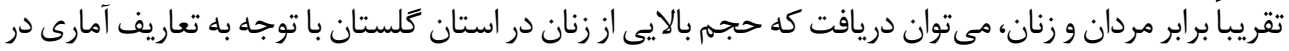

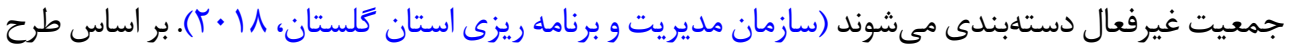

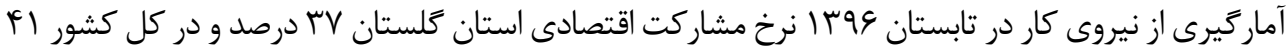

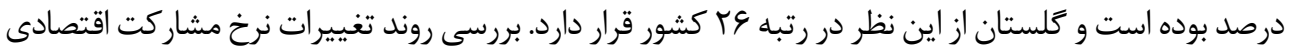

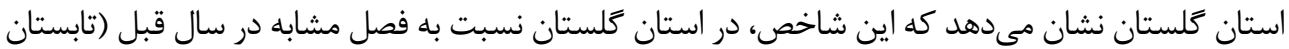

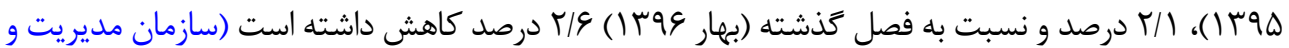

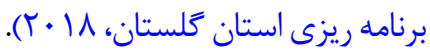

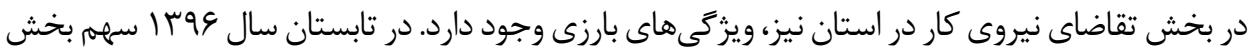

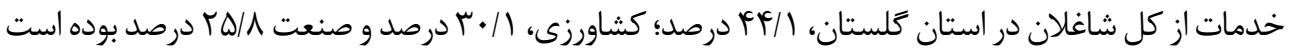

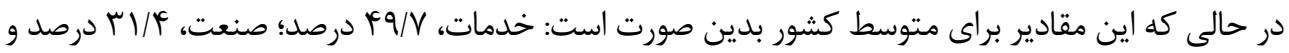

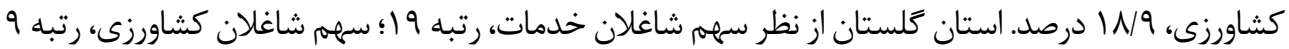

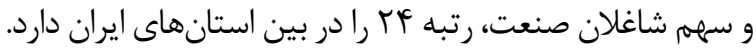

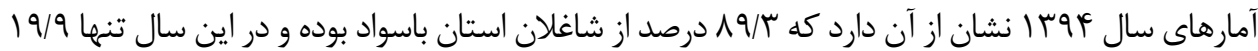

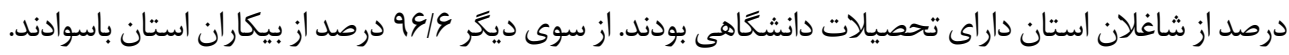

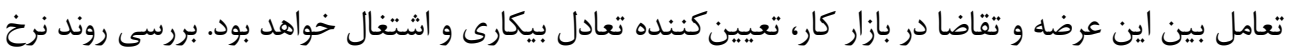

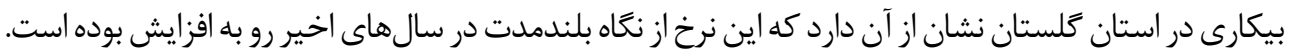

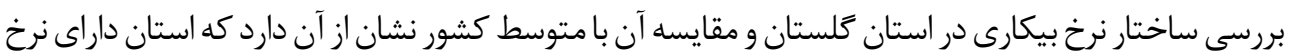

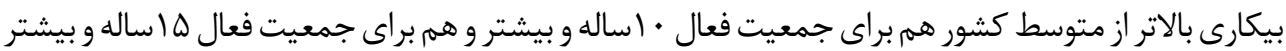


بوده است. بر اساس نتايج طرح آمار گيرى از نيروى كار در تابستان و وج ا نرخ بيكارى جمعيت • اساله و بيشتر

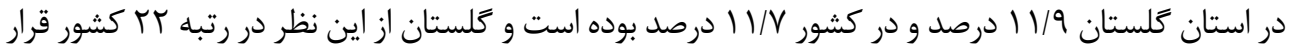

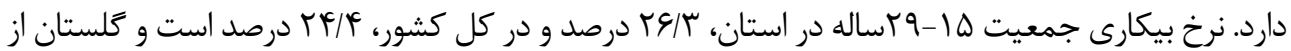

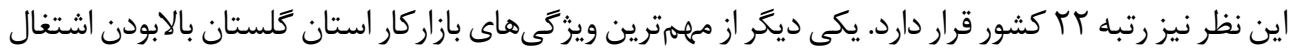

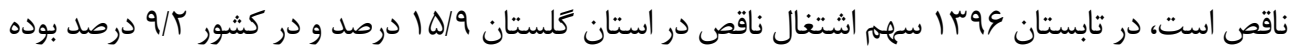

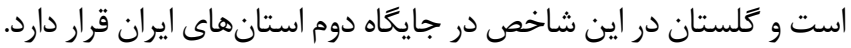

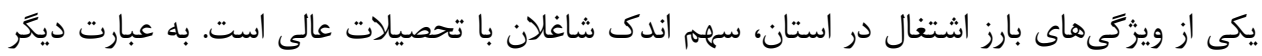

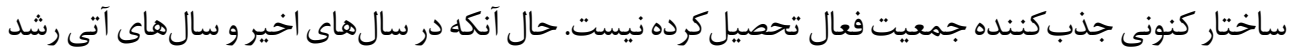

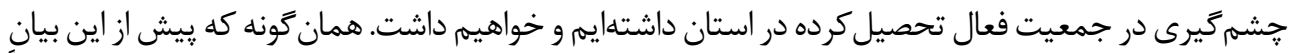

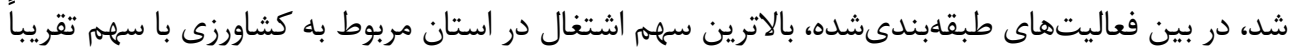

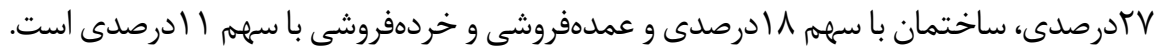

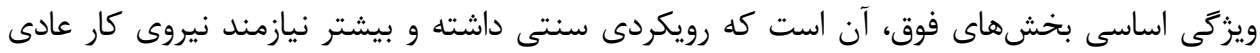

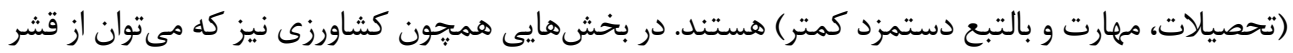

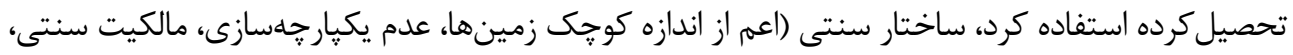

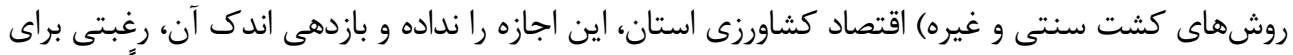

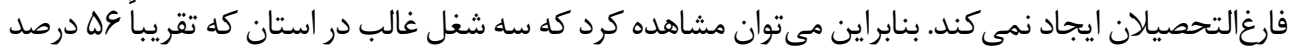

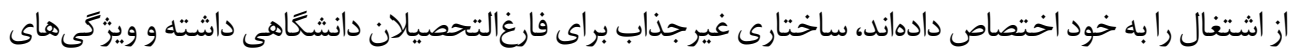

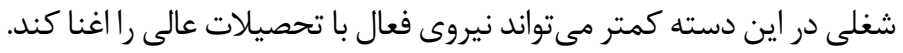

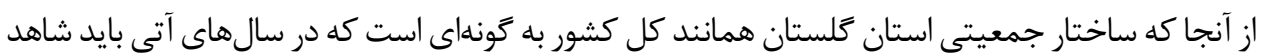

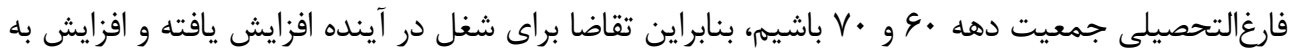

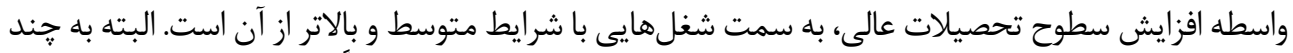

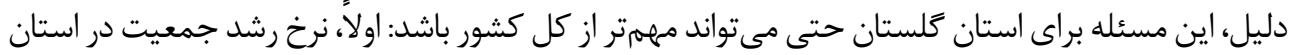

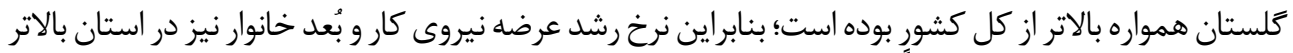

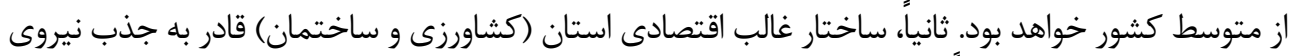

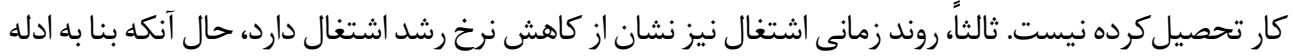

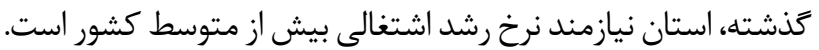

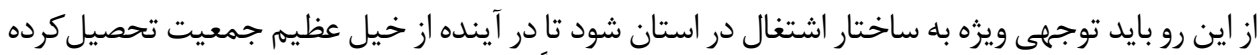

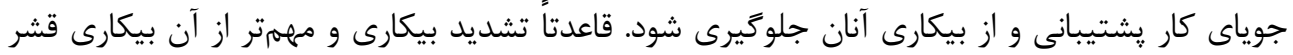

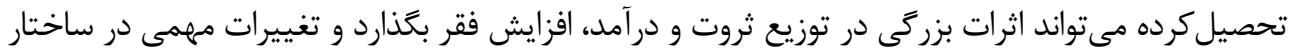

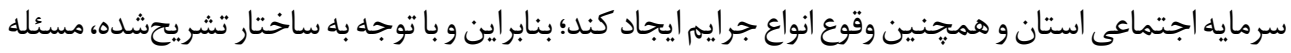

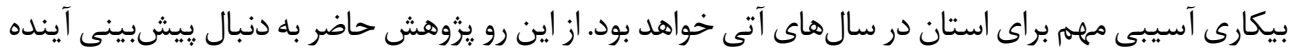




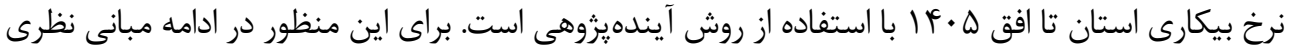

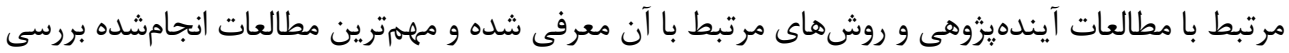

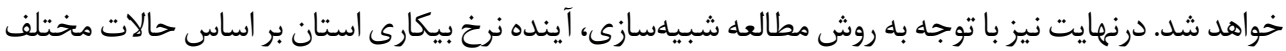
تبيين مىشود.

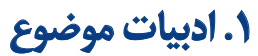

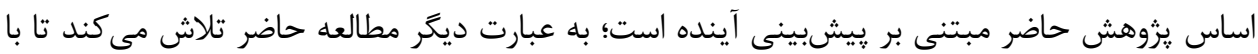

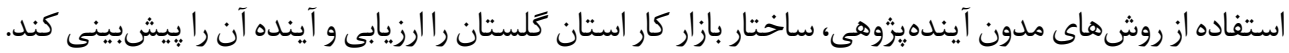

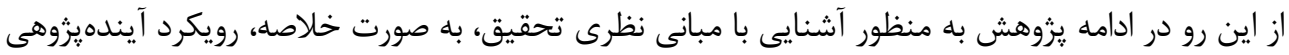

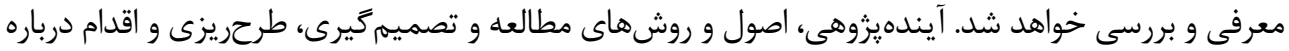

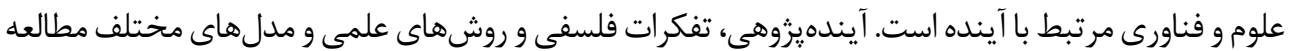

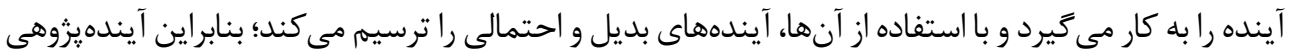

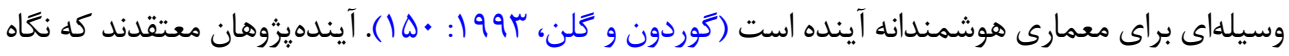

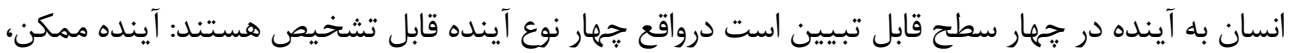

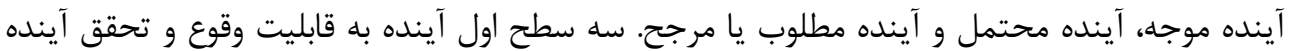

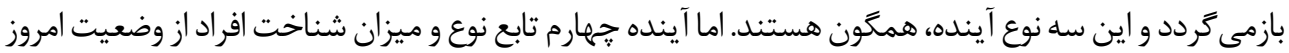

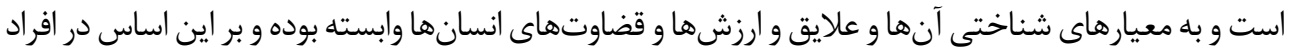

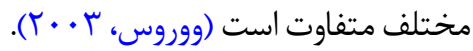

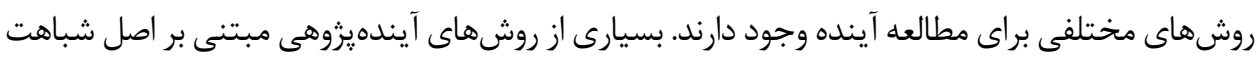

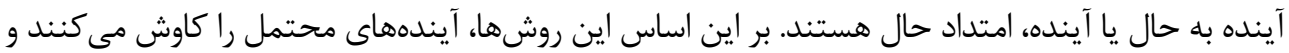

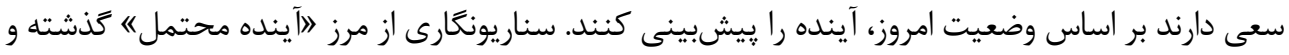

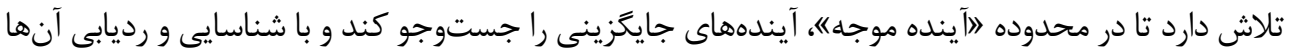

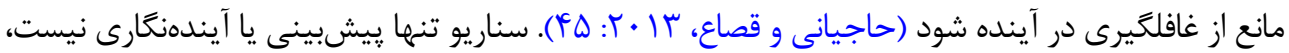

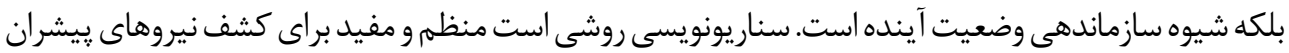

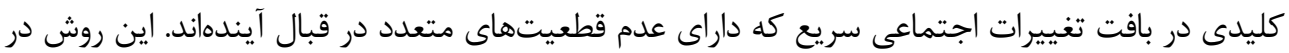

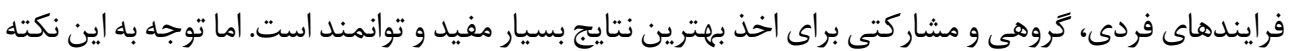

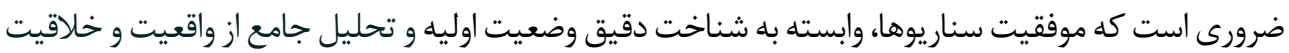

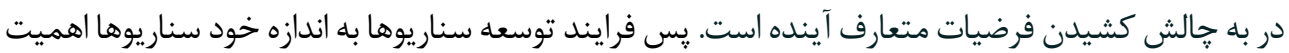

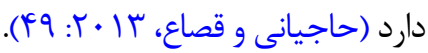

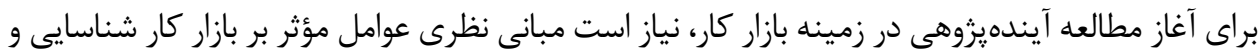

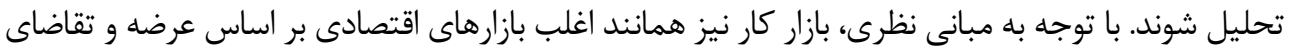

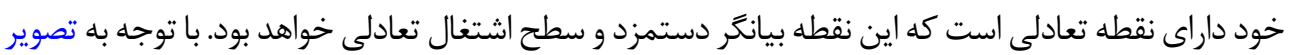




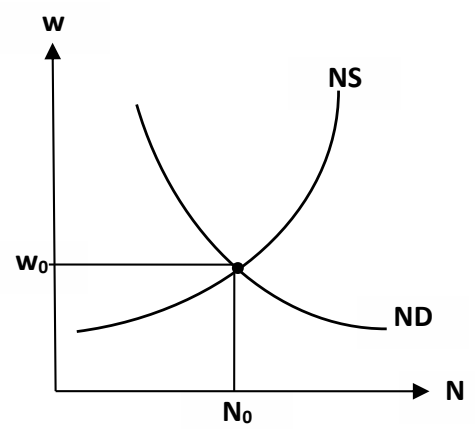

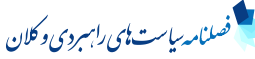

تصوير ا.عرضه و تقاضاى بازار كار و تعادل در اين بازار

شماره ا، NS نشاندهنده مقدار عرضه نيروى كار و ND نشانكَ تقاضاى نيروى كار است. جايى كه اين دو نمودار

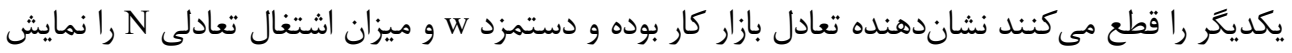

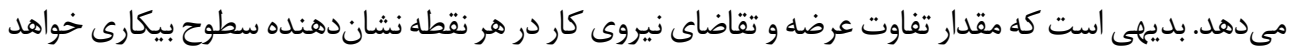

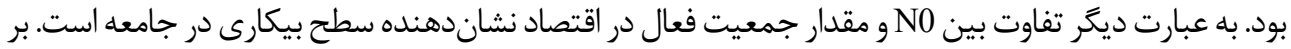

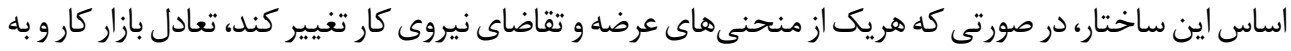

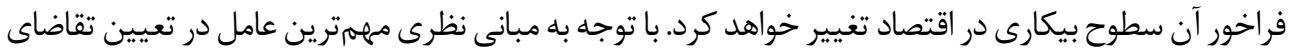

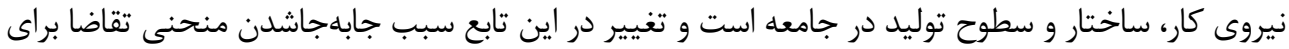

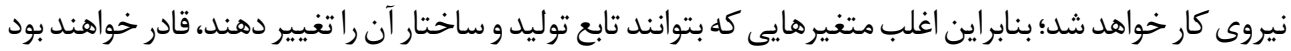

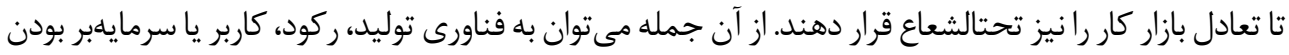

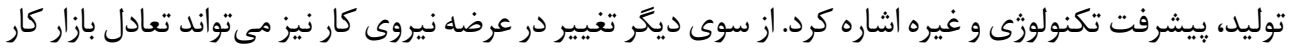

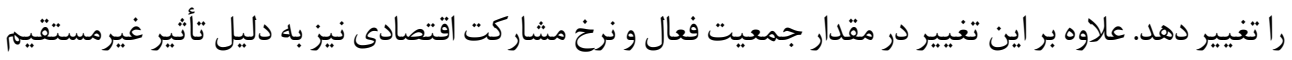

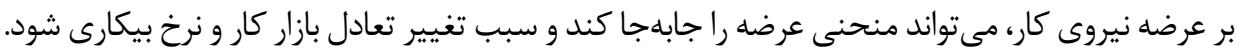

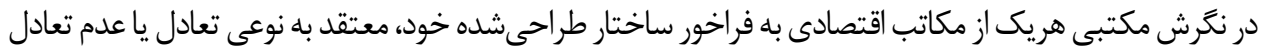

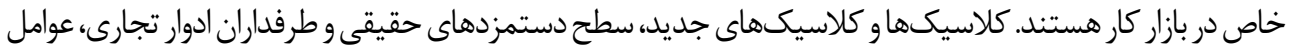

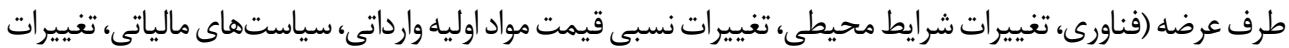

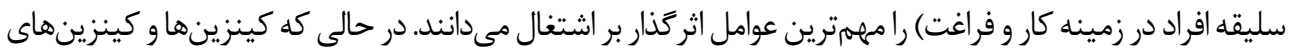

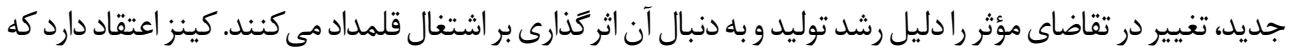

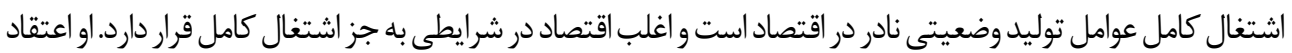

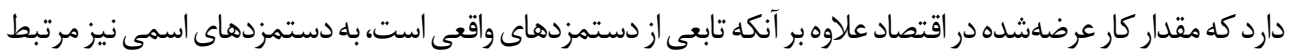

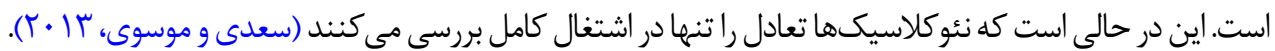


با توجه به اهميت بازار كار، هرساله مطالعات متعددى در زمينه يُ ييشبينى آينده نرخ بيكارى توسط مؤسسات

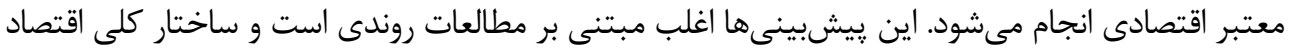

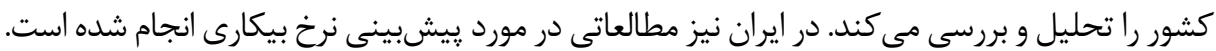
مركز يزوهش هاى مجلس شوراى اسلامى در مطالعهاى در زمينه بازار كار كشور، با استفاده از روش روندسازى

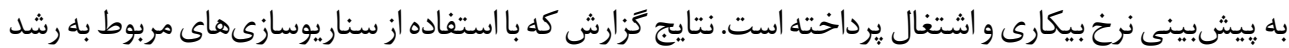

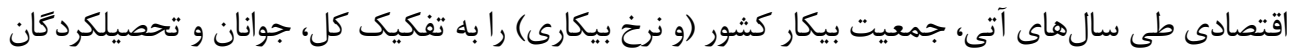

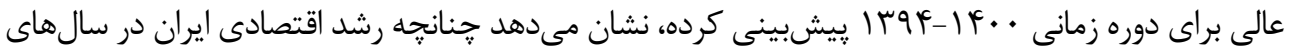

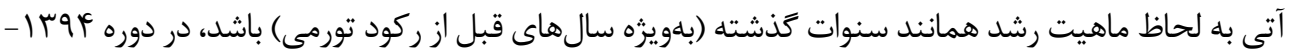

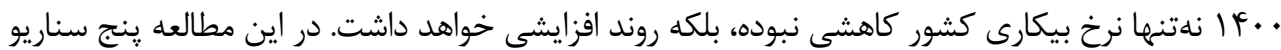

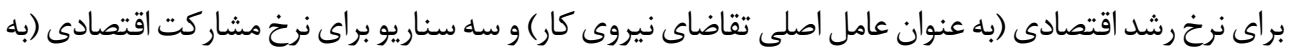

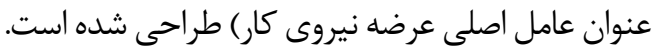

نتايج سناريوها نشان مى دهند كه جنانجه ماهيت رشد اقتصادى كشور به لحاظ توان اشتغالزايى همانند

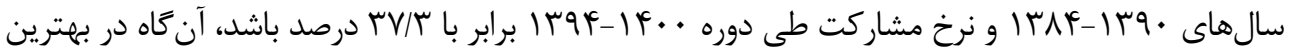

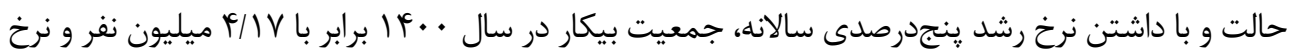

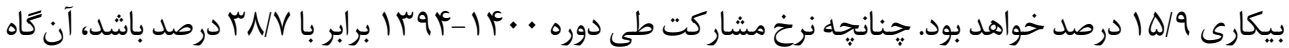

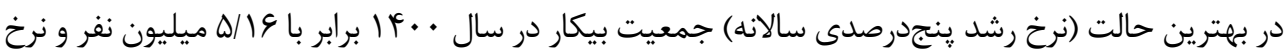

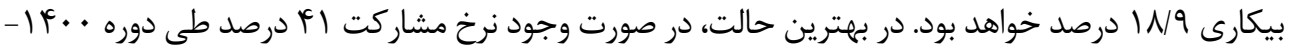

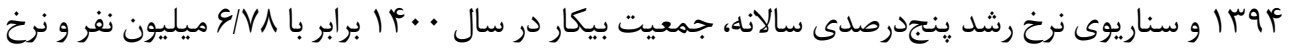

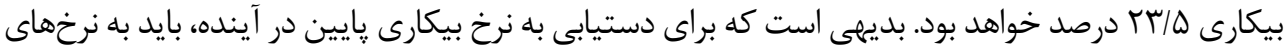

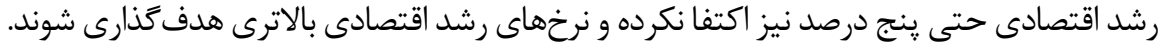

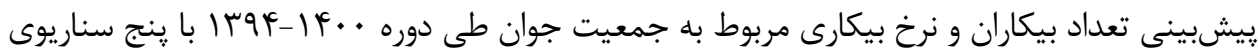

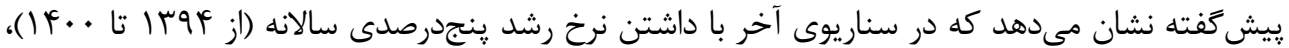

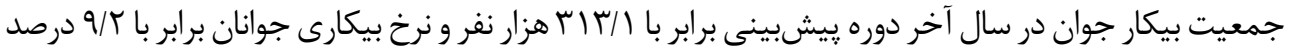

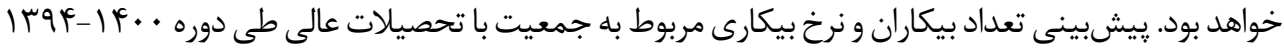

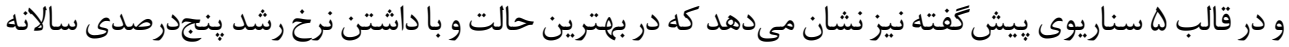

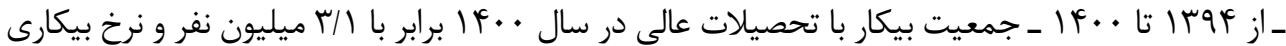

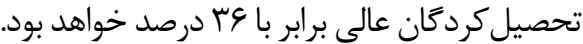

نظمفر، محمدى، زاهدى كلكى و عشقى، 9 ( • ب) با برررسى ساختار بازار كار در استان كلستان، شهرستان هاى

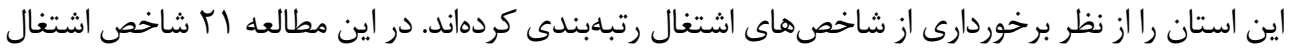

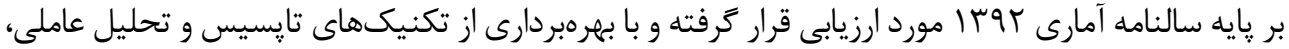

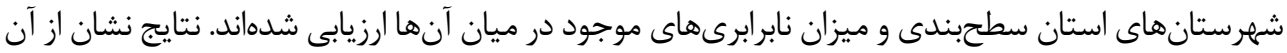




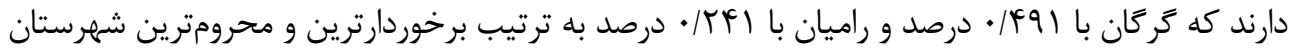

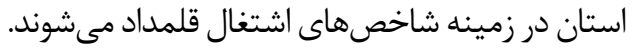

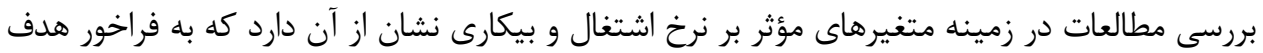

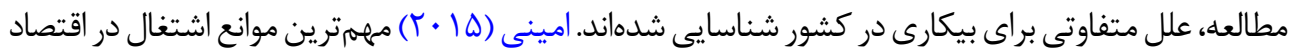

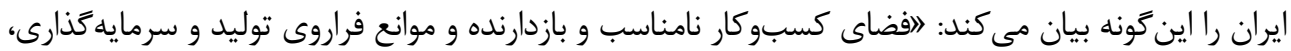

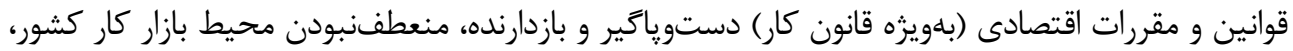

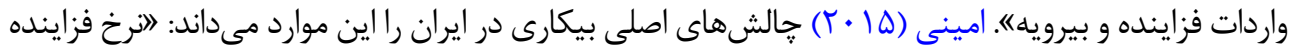

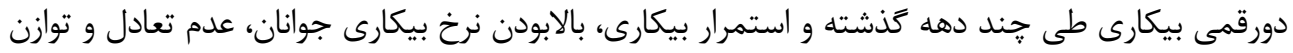

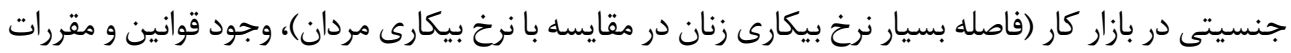

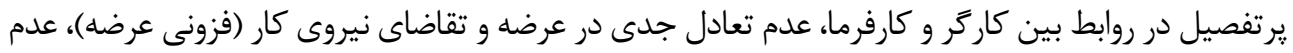

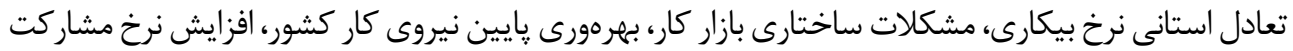

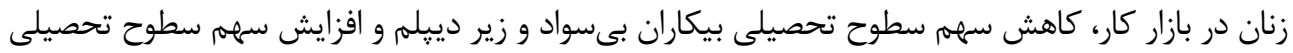

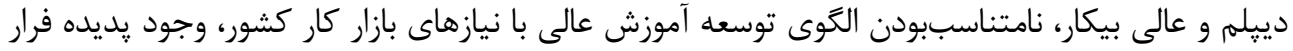

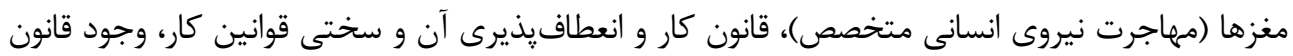

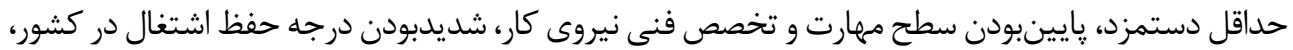

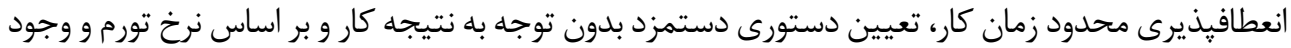
بيكارى تكنولوزيك"

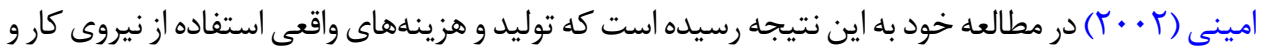

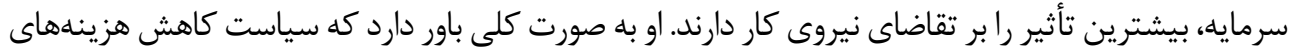

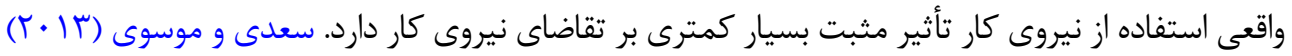

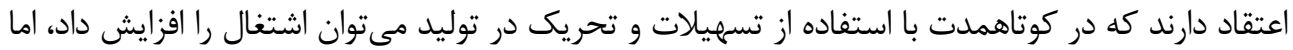

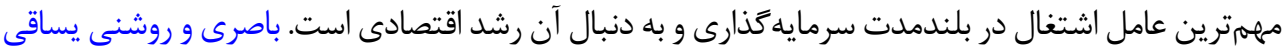

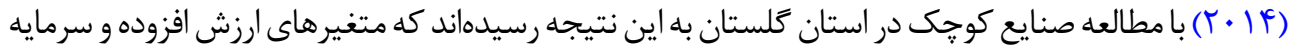

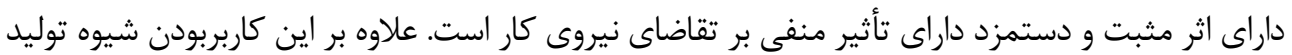
تأثير مثبتى بر ايجاد اشتغال در استان داشته است.

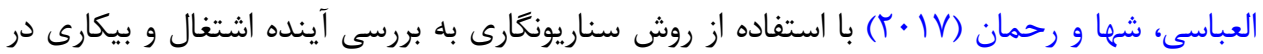

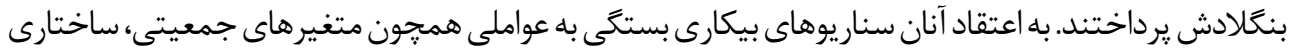

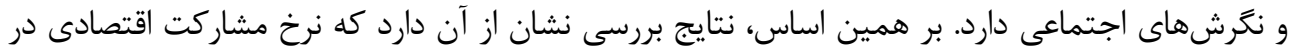

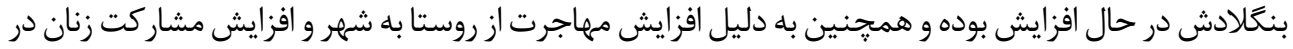

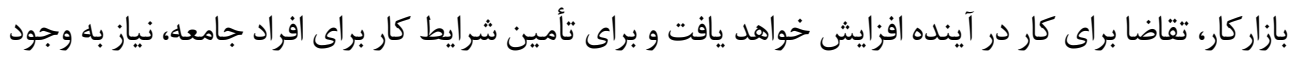

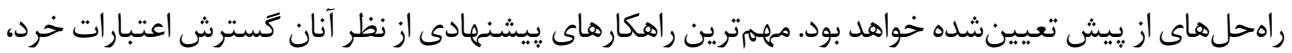


ارائه طرحهاى ويزه براى اشتغال جديد با تمركز بر مهارتهاى افراد و تقاضاى نوين كار در بازار جهانى است.

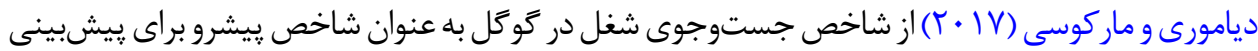

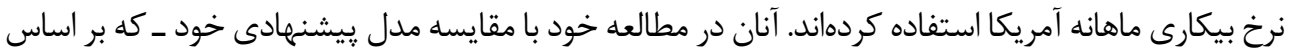

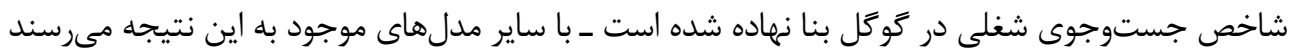

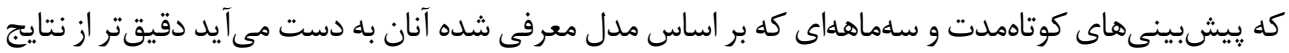
ساير مدلهاست.

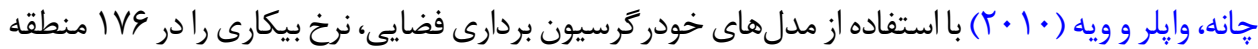

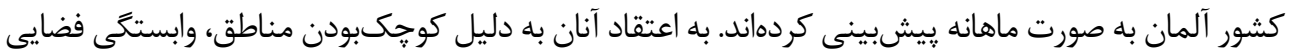

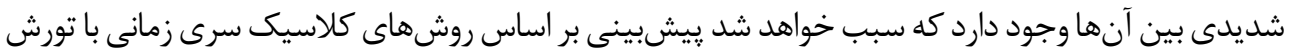

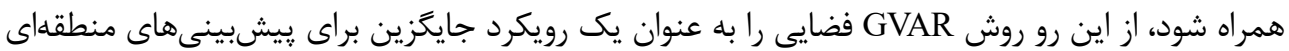
ي يشنهادمى كنند.

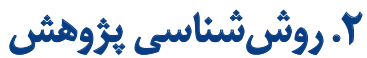

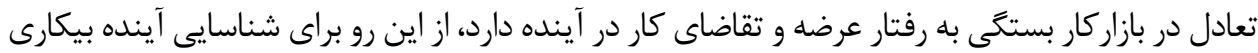

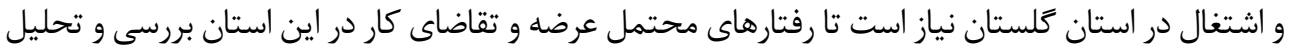

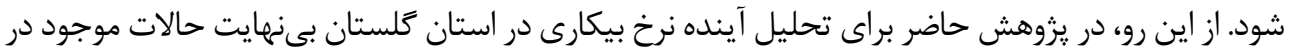

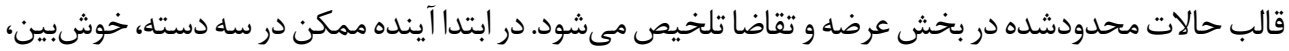

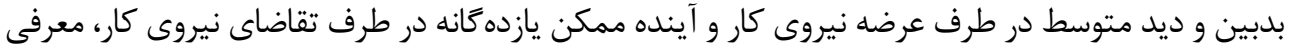

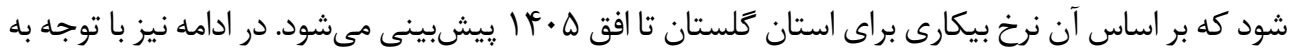

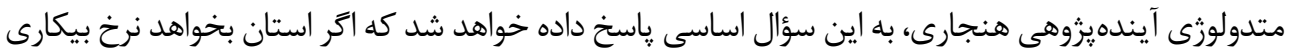

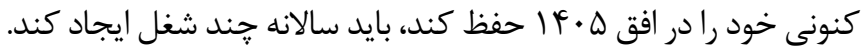

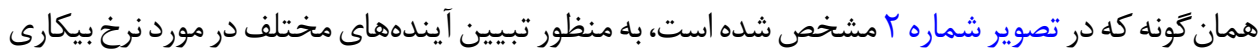

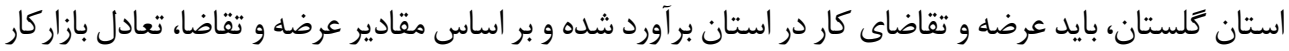

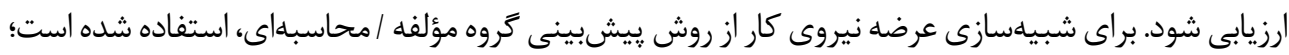

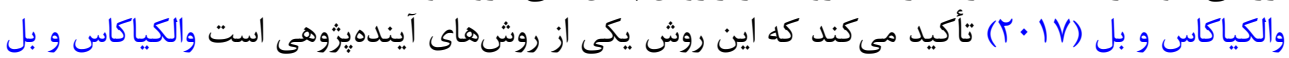

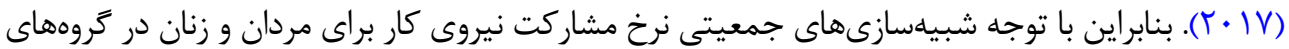

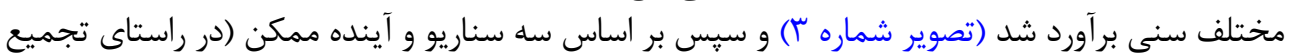

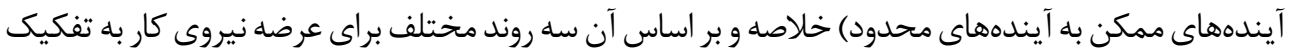

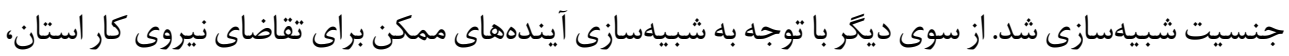

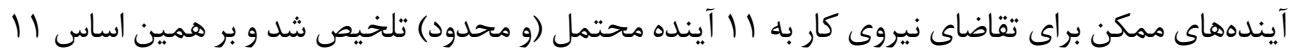

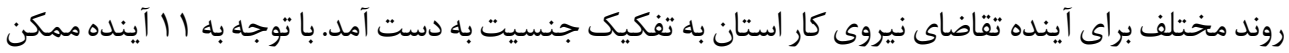




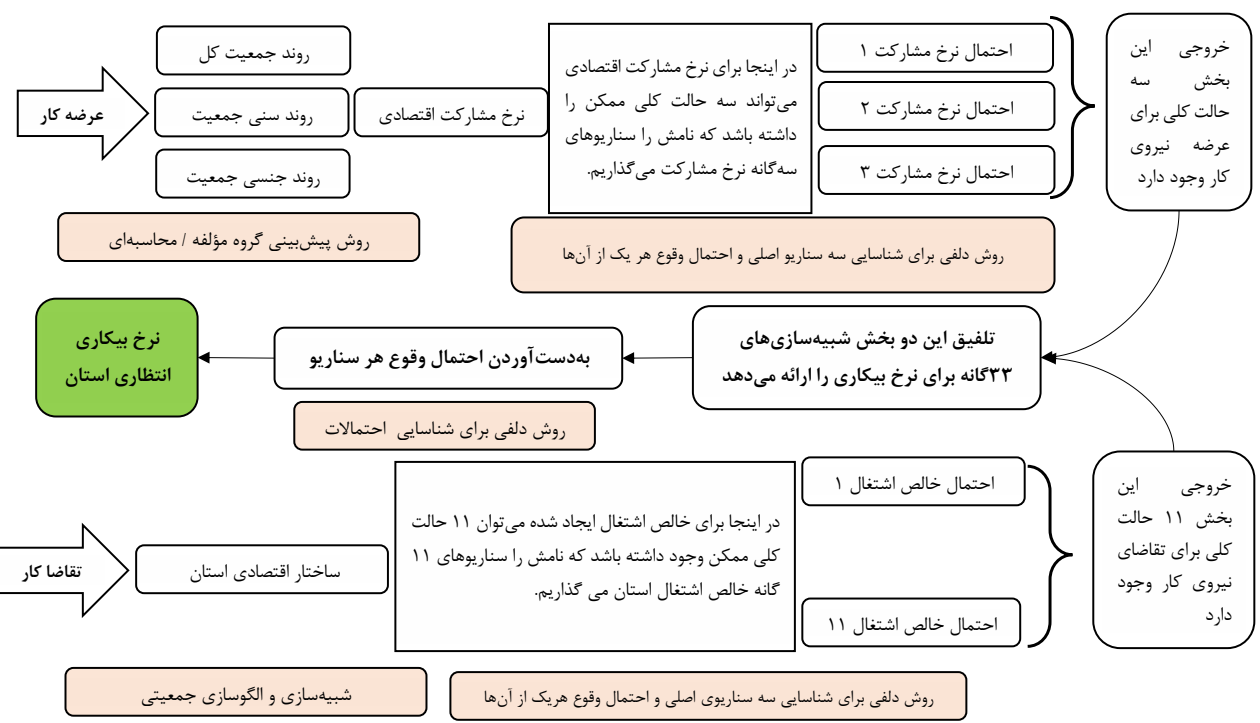

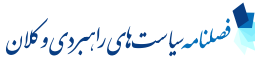

تصوير זّ. برآورد عرضه و تقاضاي كار در استان

(محدودشده) در طرف تقاضاى نيروى كار و سه آينده ممكن (محدودشده) در طرف عرضه نيروى كار استان

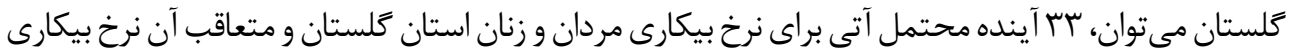
كل استان كلستان به دست آوران

در مرحله بعد با استفاده از نظر خبر گان و روش دلفى، احتمال وقوع هريك از حالات سه كانه در عرضه نيروى دان

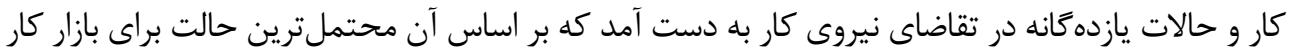

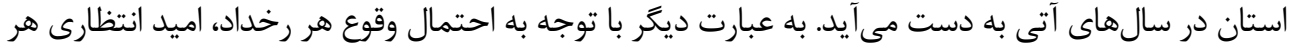

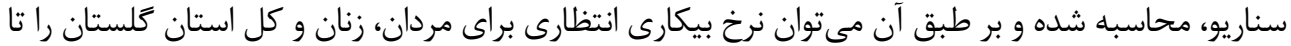
سال ه • أ أ محاسبه كرد.

با توجه به عقبه استان در بخش تقاضاى نيروى كار، فرض مى شود بازه ايجاد شغل خالص از صفر شغل تا

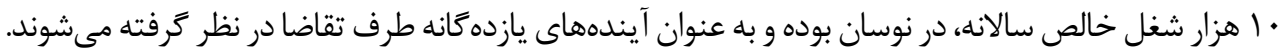

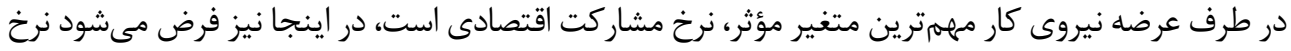

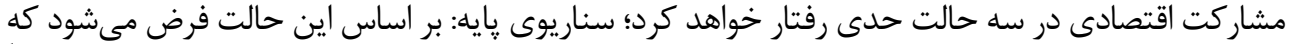

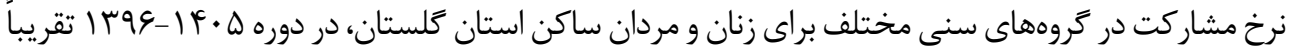

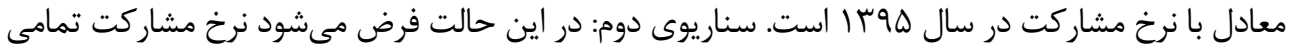




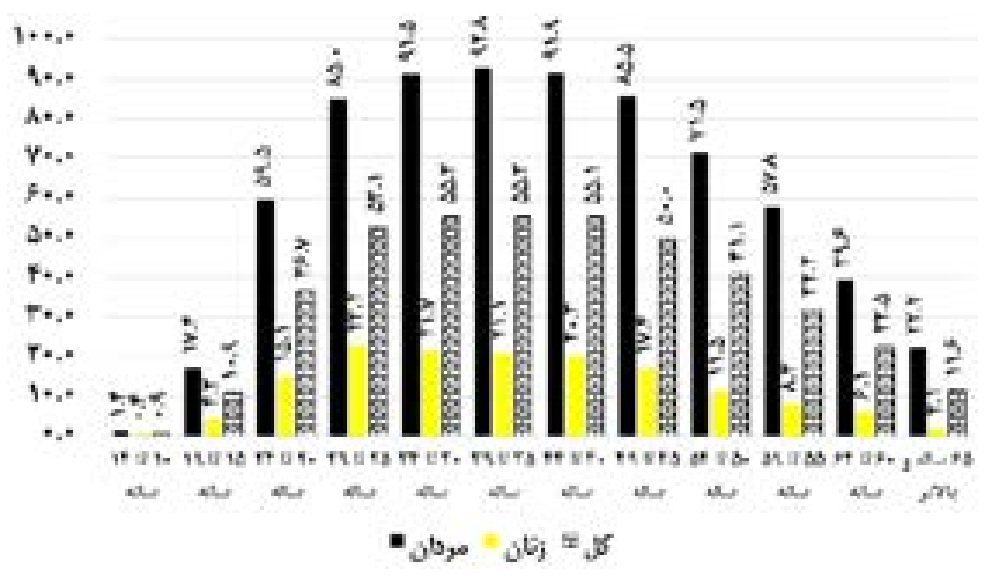

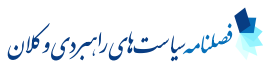

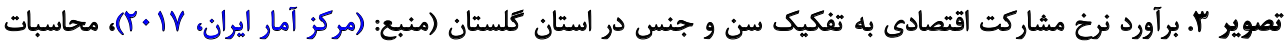
تيروهشي)

گروههاى سنى در استان كلستان براى زنان و مردان نسبت به سناريوى يايهاى، • أ درصد افزايش يابد. سناريوى

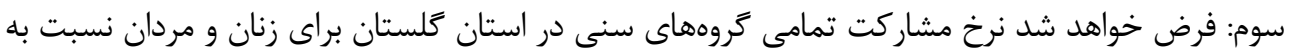

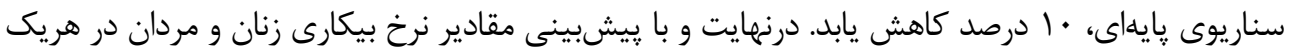

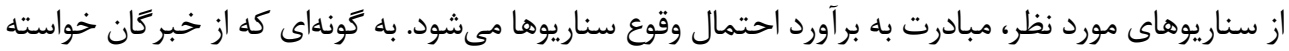

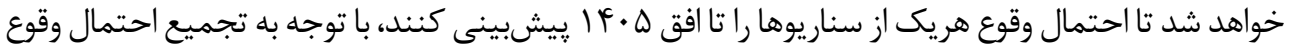

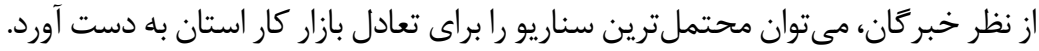

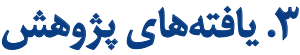

شبيه سازى نرخ بيكارى با توجه به بر آوردهاى جمعيتى صورت گرفته، مىتوان جمعيت استان گلستان را تا

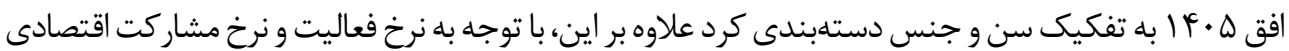

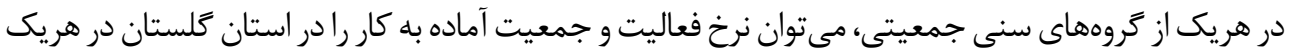

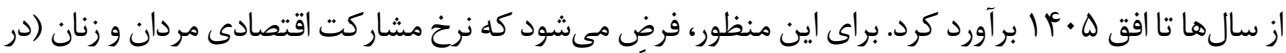

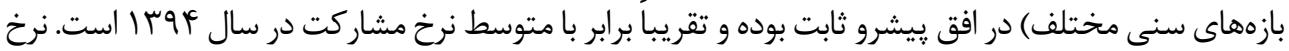

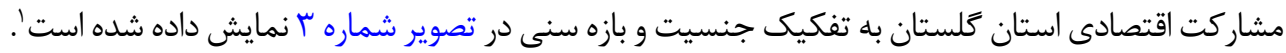
با توجه به مقدار نرخ مشاركت اقتصادى، مىتوان جمعيت آماده به كار براى هريك از دستههاى زنان و مردان

ا. به دليل عدم دسترسى به اطلاعات خام با تفكيك تمام كروهاه

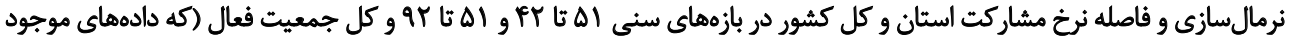




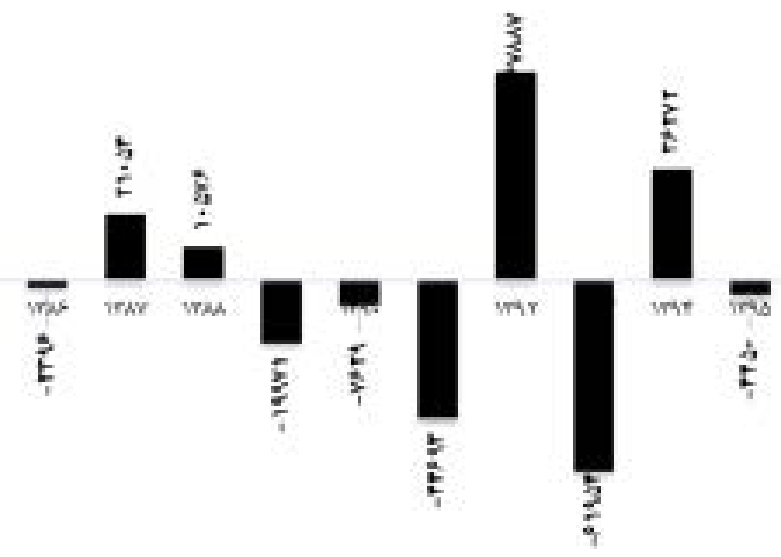

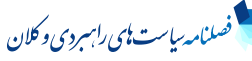

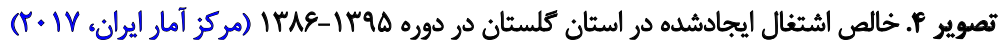

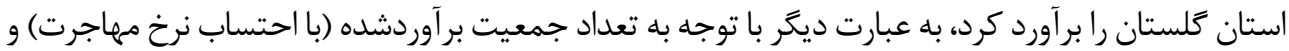

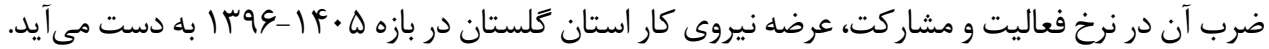
از سوى ديگر تعادل بازار كار توسط تعامل عرضه و تقاضاى كار به دست خواهد آمد، از اين رو تقاضاى كار

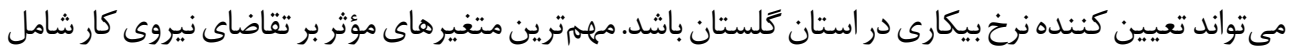

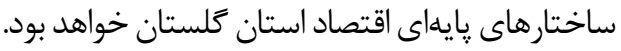

براى محاسبه تقاضاى نيروى كار روش هاى مختلفى وجود دارد؛ براى مثال مى توان از ساختار توليد ناخالص

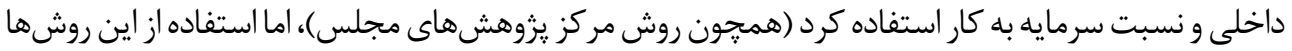

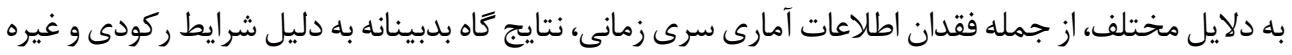

بودند)، بقيه بازهماى سنى براى استان كلستان با توجه به آمارهاى كثور و تمايز مشاركت استان و كشور برآورد و شبيهسازى شود.

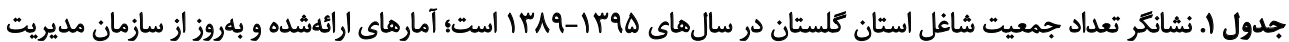

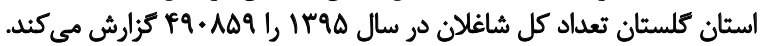

\begin{tabular}{|c|c|c|c|c|c|c|c|}
\hline 1790 & irgf & irar & irar & |rq| & irq. & 1ra9 & سال \\
\hline pqlfr & $p q \Delta r+q$ & poq.rV & $\Delta r+991$ & forl.f & $\Delta .+r q u$ & 01.991 & كل \\
\hline$f+1989$ & FIATYq & rq. & PTTAL. & $M T I D A$ & $f+\Delta .8 \varepsilon$ & $r+r V E I$ & مرد \\
\hline$A T \Delta+\Delta$ & va9v9 & SAFt. & uffi & VIVET & QDTHT & 1.ATHE & ن \\
\hline
\end{tabular}


جندان مفيد نخواهد بود. به همين دلايل، سناريوها بريايه تعداد خالص اشتغال ايجادشده در استان كلستان

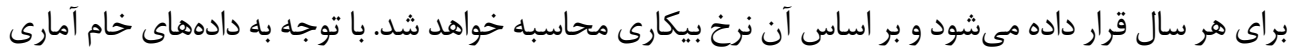

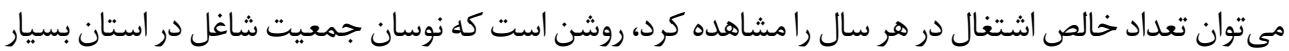

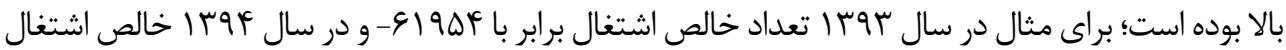

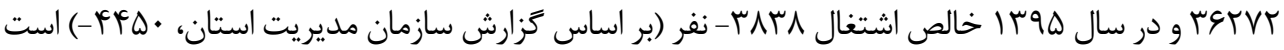

$$
\text { (تصوير شماره أ و جدول شماره (1). }
$$

بديهى است اين تغييرات مقطعى بوده و نمىتوان از آنها به عنوان تغييرات بلندمدت استفاده كرد؛ از اين رو آنا

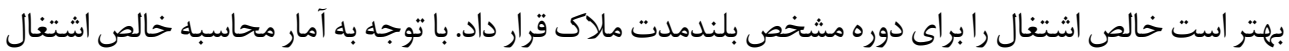

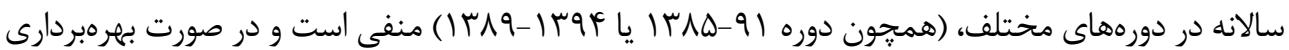

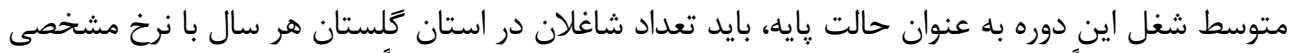

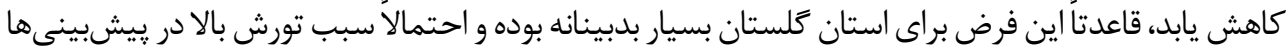

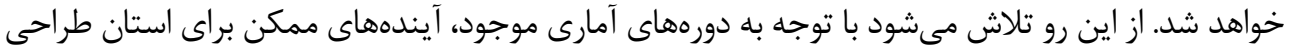

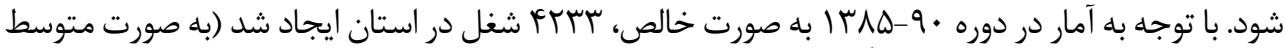

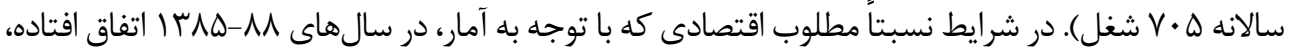

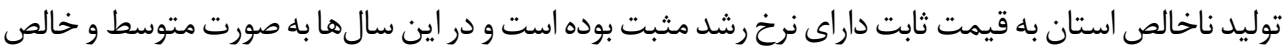

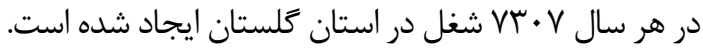

از اين رو تعامل تمامى عوامل مؤثر در طرف تقاضا، درنهايت منجر به مقادير مشخصى از تقاضاى نيروى كار

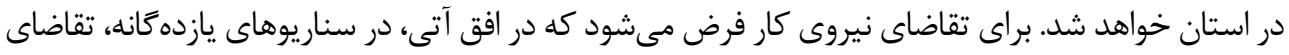

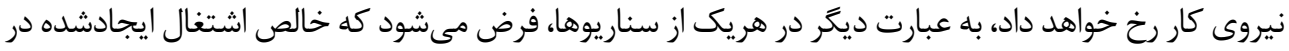

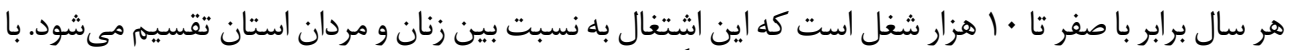

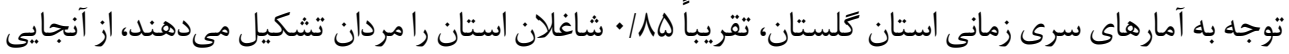

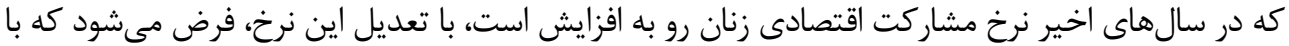

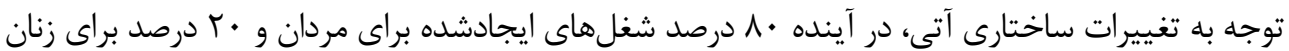

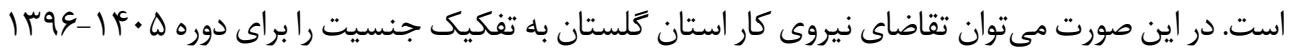
برآورد كرد.

با توجه به برآوردهاى صورت گرفته براى عرضه و تقاضاى نيروى كار استان كلستان، مى توان نرخ بيكارى

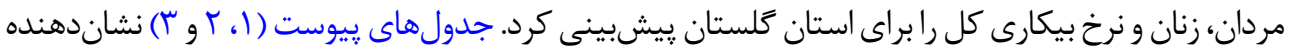

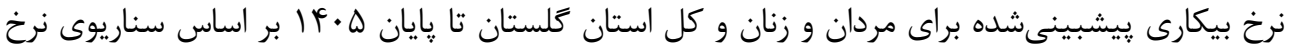

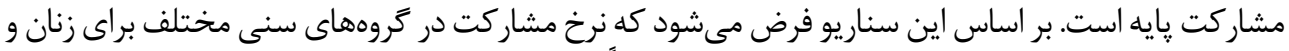

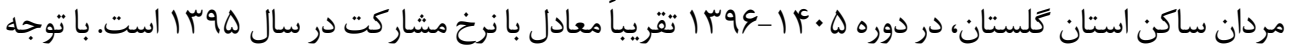

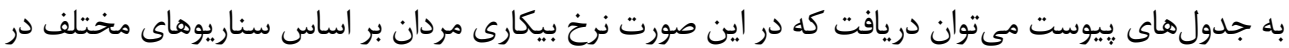


جدول r. احتمال وقوع آيندههاى ممكن طرف عرضه نيروى كار

\begin{tabular}{|c|c|c|c|}
\hline افزايش نرغ مشاركت & نرغ مشاركت ثابث & كاهش نرخ مشاركت & سناريو \\
\hline . MTA &.$/ F i a$ &.$/ 4 \%$ & احتمال وقوع \\
\hline
\end{tabular}

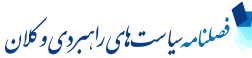

جدول بّ. احتمال وقوع آيندهاى ممكن طرف تقاضاى نيروى كار

\begin{tabular}{|c|c|c|c|c|c|c|c|c|c|c|c|}
\hline+4 & + & +4 & $V++$ & $9+\cdots$ & $\Delta+\cdots$ & $f++$ & $r+\ldots$ & $r++$ & $1+4$ & صفر & خالص شغل \\
\hline$+|+4|$ & 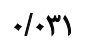 & $+1+94$ & +1.94 & ./NFA & $+/ 1 \Delta \Delta$ &.$/ 1 f a$ & ./TKE &.$/ 118$ & $+/+\Delta H^{\mu}$ &.$/+4 I$ & احتمال وقوع \\
\hline
\end{tabular}

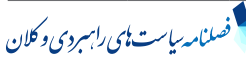

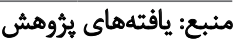

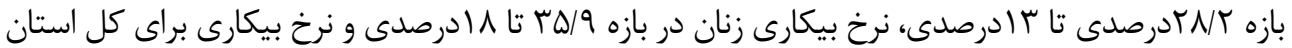

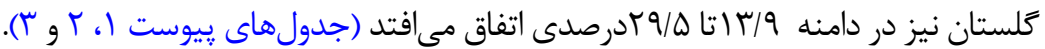

در سناريوى دوم عرضه نيروى كار، فرض مىشود نرخ مشاركت تمامى گروههاى سنى در استان گلستان براى

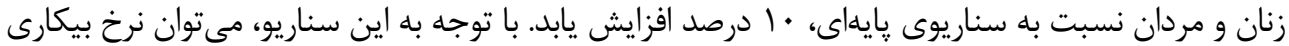

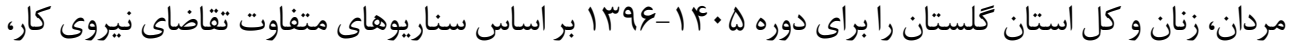

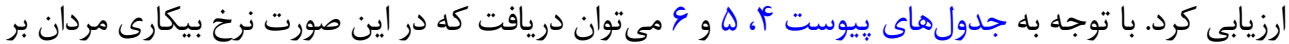

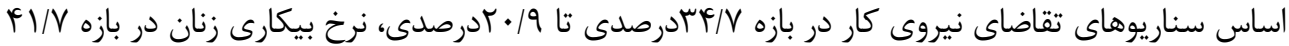

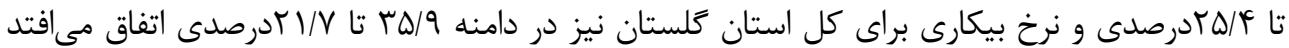

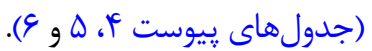

در سناريوى سوم عرضه نيروى كار، فرض مىشود نرخ مشاركت تمامى گروههاى سنى در استان كلستان

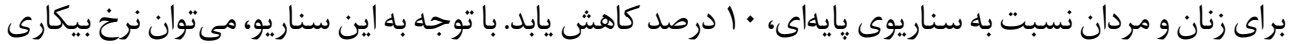

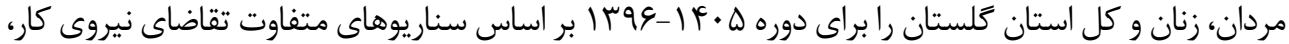

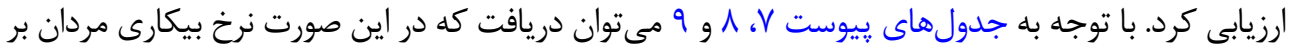

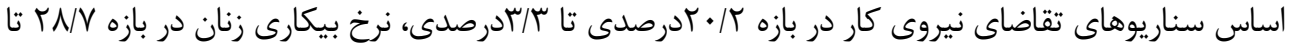

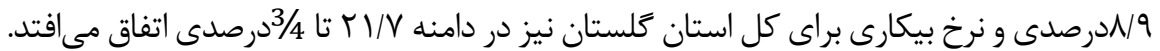

درنهايت براى شناسايى محتملترين آينده ييشروى استان كلستان در زمينه نرخ بيكارى بايد احتمال

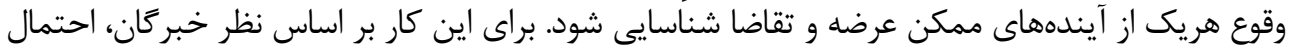

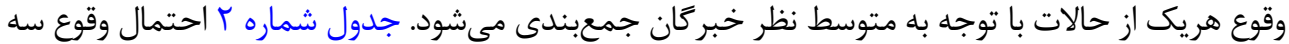

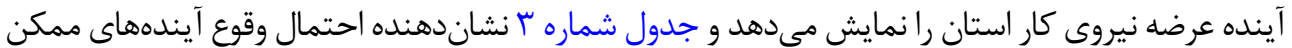

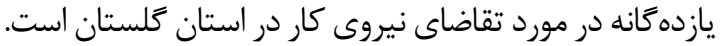




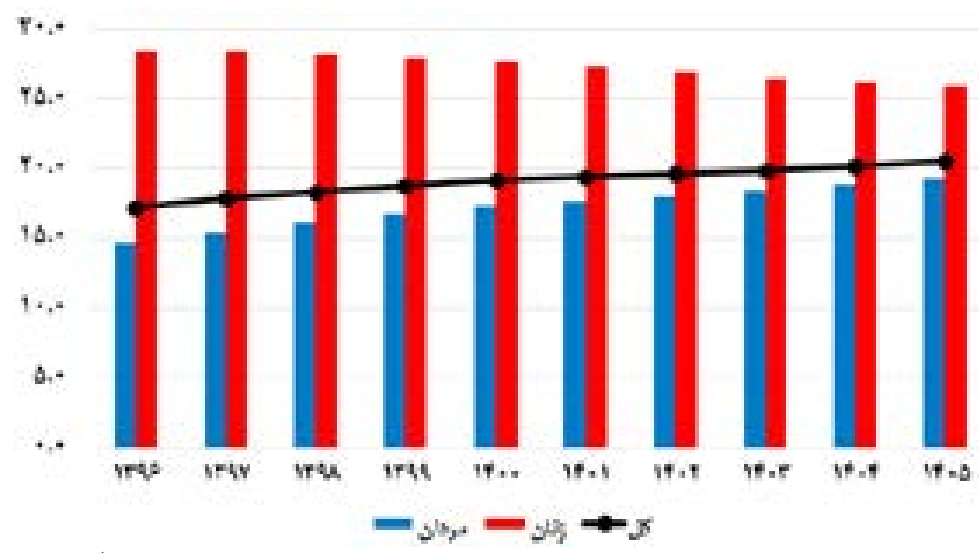

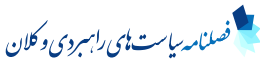

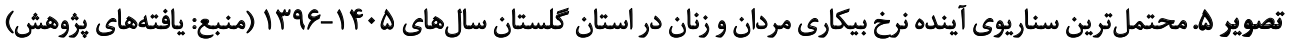

با توجه به احتمال وقوع هريك از حالات مىتوان محتملترين آينده براى نرخ بيكارى استان (به عبارت

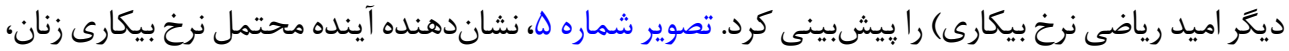

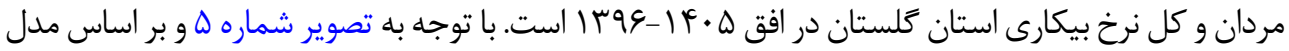

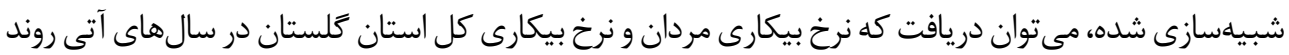

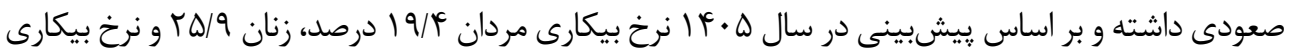

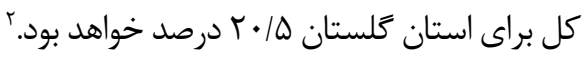

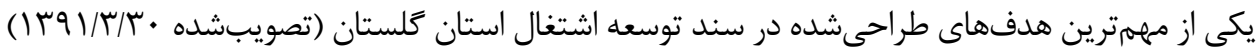

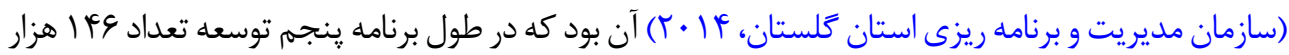

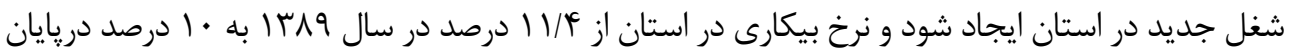

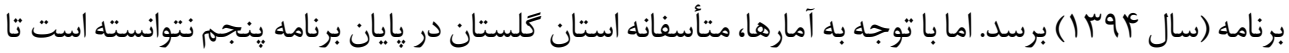
به اين نرخ بيكارى نائل آيد.

بديهى است به منظور رسيدن به نرخ بيكارى هدف، بايد بر اساس ساختار جمعيتى، ميزان خالص شغل مورد

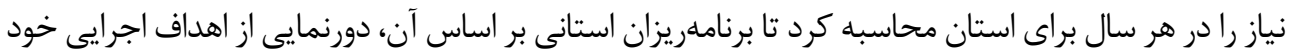

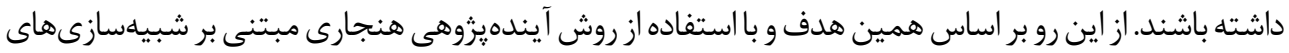

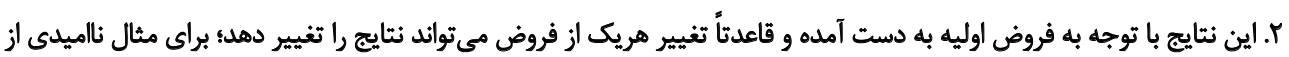

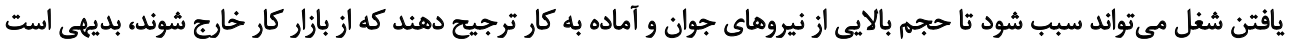

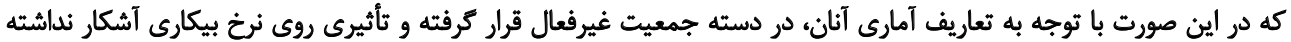

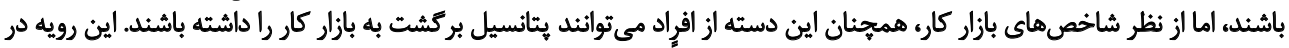

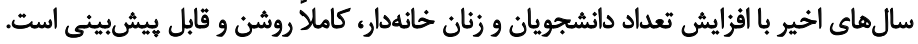




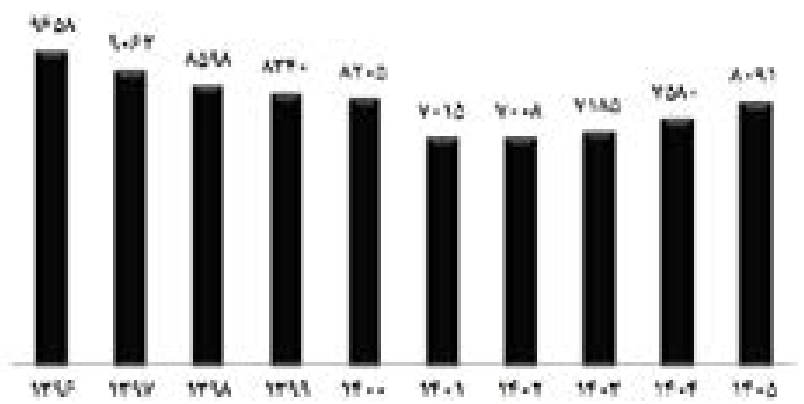

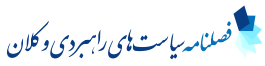

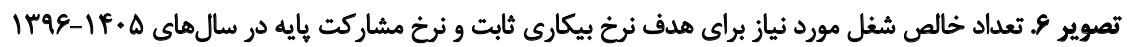

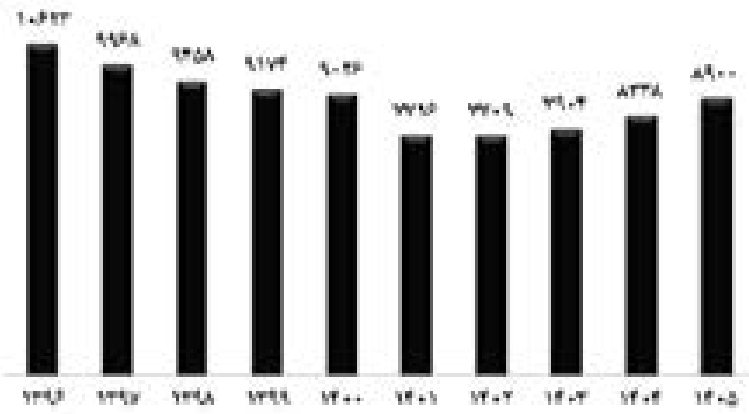

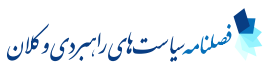

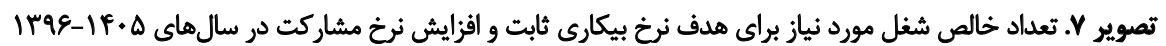

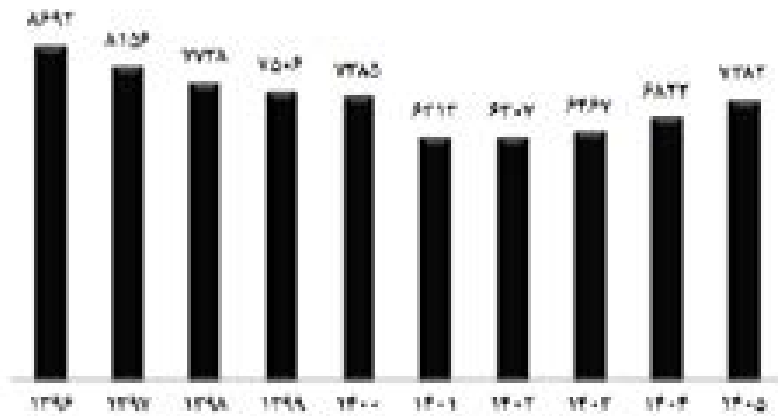

(2)

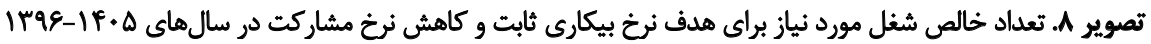


انجامشده مى توان به اين سؤال اساسى نيز ياسخ داد كه اگر استان گلستان بخواهد از نظر ساختار نرخ بيكارى

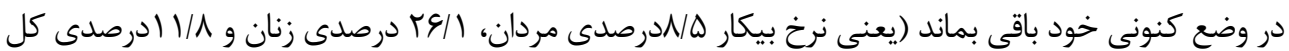

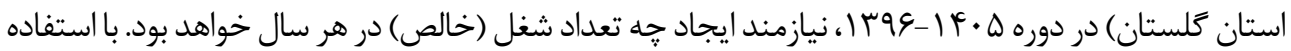

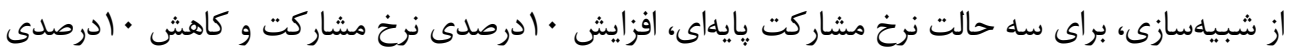

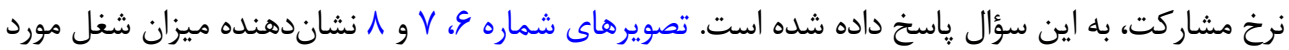

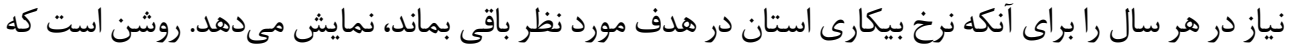

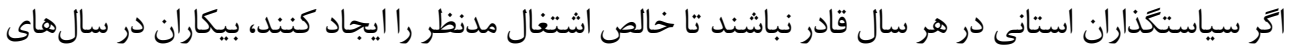

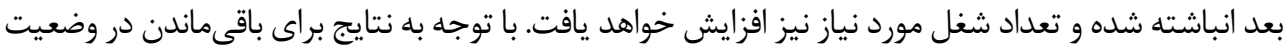

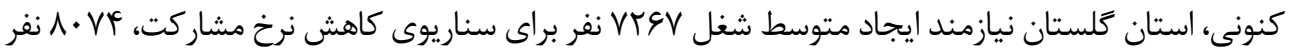

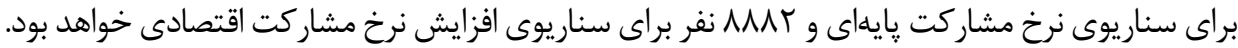

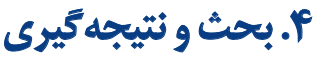

بيكارى معضلى است كه تمامى ابعاد زندگى فردى و اجتماعى افراد را تحتالشعاع قرار مى مدهد و ارتباط

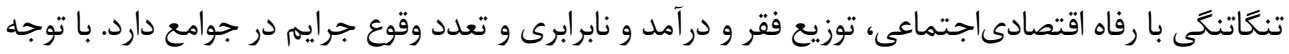

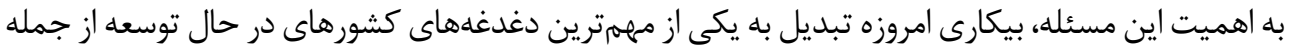

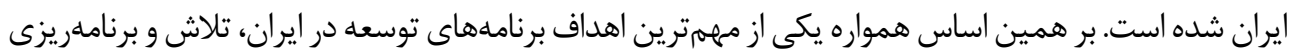

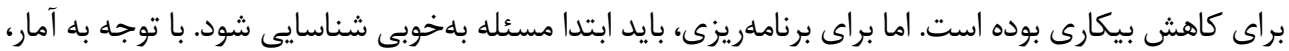

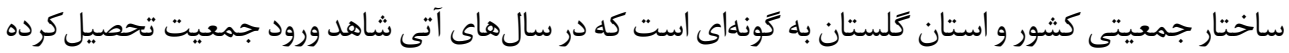

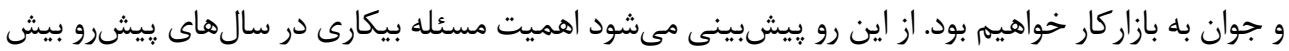

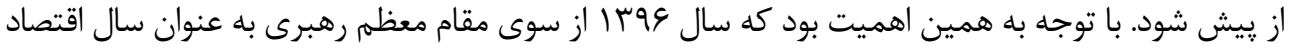

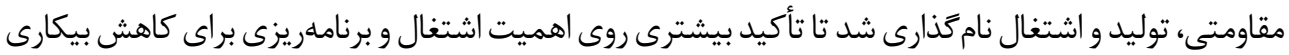

$$
\text { در كشور صورت يذيرد. }
$$

بديهى است برنامهريزى بلندمدت براى اين مسئله مهلم، بدون داشتن دورنمايى از آينده بيكارى غيرممكن

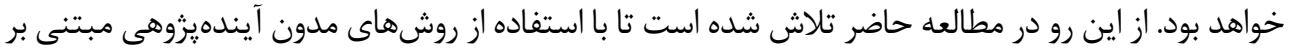

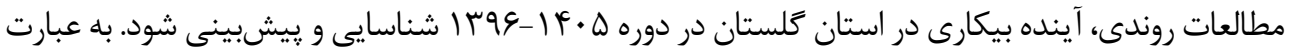

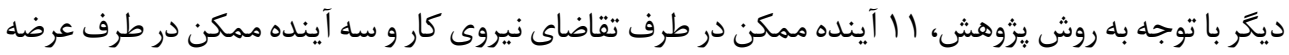

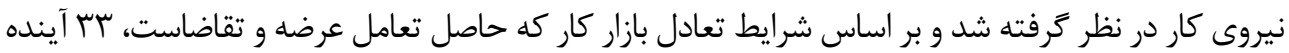

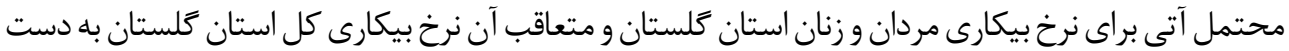

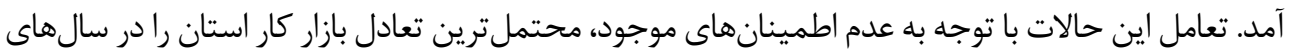

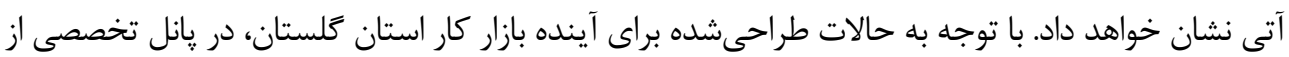

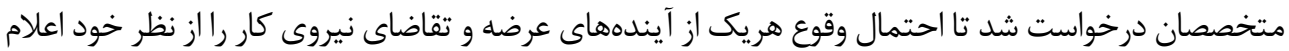

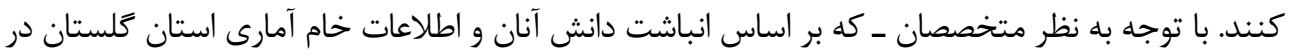




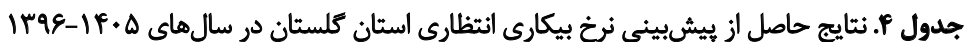

\begin{tabular}{|c|c|c|c|}
\hline كل & زنان & مردان & سال \\
\hline$I V / T$ & TNF & $1 F / V$ & Irge \\
\hline IV/A & TNF & $\mid \Delta / \Delta$ & Irq9 \\
\hline$W^{N}$ & TNT & 181 & ira \\
\hline WA & rN. & $18 / V$ & 11499 \\
\hline $19 / r$ & $r V / V$ & $I V / r$ & $1 f+$. \\
\hline $19 / 6$ & $r V / r$ & $I V / V$ & $10+1$ \\
\hline $19 / 8$ & $r E / q$ & W. & $1 r+r$ \\
\hline $19 / 9$ & $r E / \Delta$ & WF & $1 f \cdot r$ \\
\hline$r+/ r$ & $r E / T$ & Wa & $1 f+f$ \\
\hline$r+/ \Delta$ & $r \Delta / q$ & $19 / 4$ & $1 f+\Delta$ \\
\hline
\end{tabular}

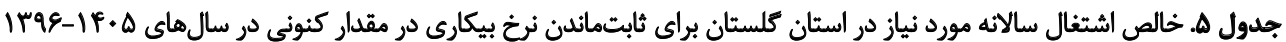

\begin{tabular}{|c|c|c|c|c|}
\hline محتملترين سناريو & كاهش مشاركت & افزايش مشاركت & مشاركت بايه & سناريو / سال \\
\hline QATV & Neqr & $1.9 \pi$ & 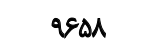 & $1{ }^{m}$ \\
\hline 1qi. & $1 / \Delta F$ & 998 & 9.95 & Irav \\
\hline APAT & $m+\Lambda$ & $9 P \Delta \Lambda$ & $10 Q 4$ & 1 wa \\
\hline ATrV & $V \Delta . G$ & qive & Arft. & 11799 \\
\hline $1+9 \Delta$ & $V$ VAs & $q . r q$ & $A T \cdot \Delta$ & If.. \\
\hline gar. & זוT & WIE & $\gamma \cdot 10$ & $1 F+1$ \\
\hline eqIr & $g^{r} \cdot V$ & $w \cdot q$ & $V \cdot \cdots 1$ & $1 f \cdot r$ \\
\hline$V \cdot M$ & eper & vq.p & VMA & $1 f \cdot r$ \\
\hline neva & SATY & גוזנו & VOA. & If.f \\
\hline var & VAT & $19 .$. & 1.91 & $1 f \cdot \Delta$ \\
\hline VQSD & VYV & MUT & $1+V^{f}$ & متوسيط \\
\hline
\end{tabular}

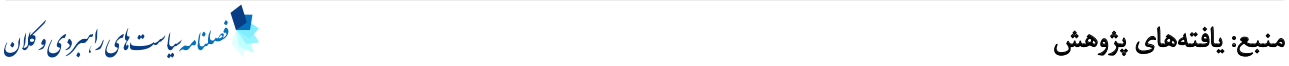




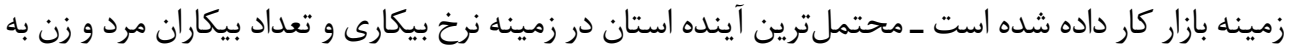

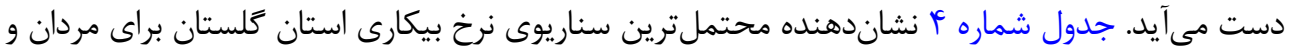
زنان است.

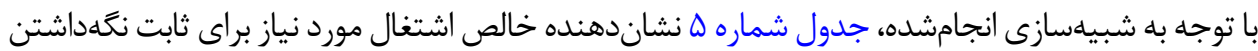

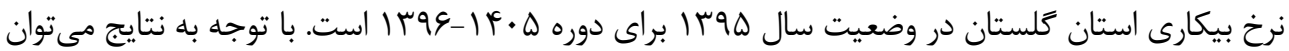

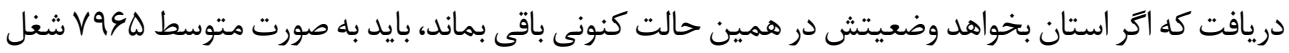

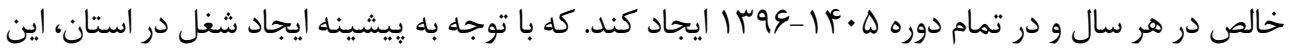

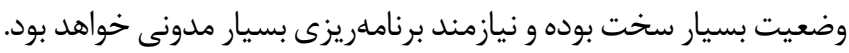

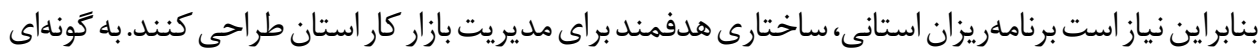

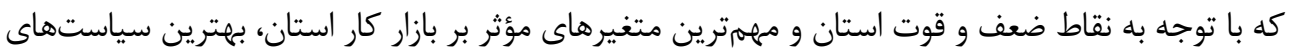

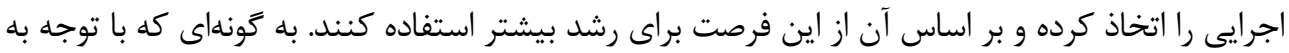

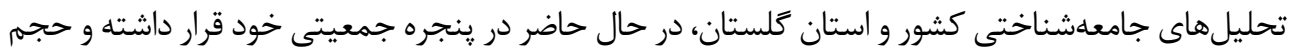

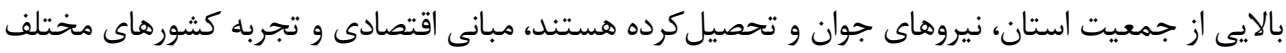

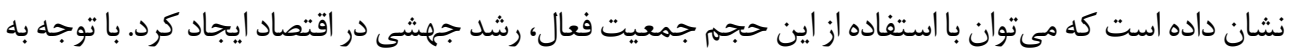

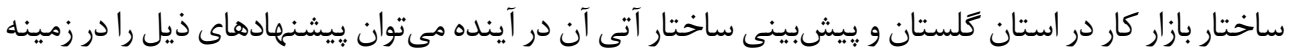

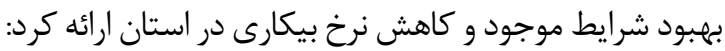

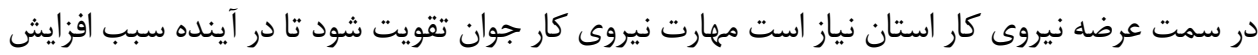

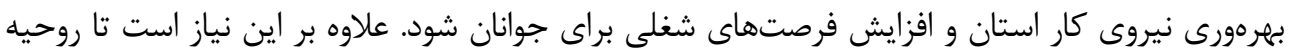

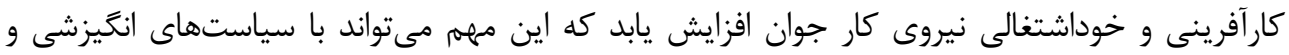

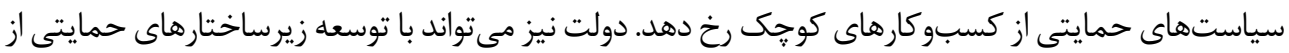

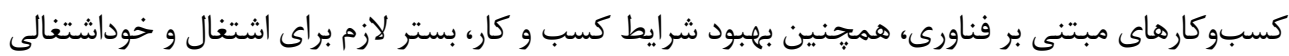

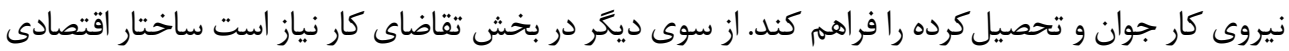

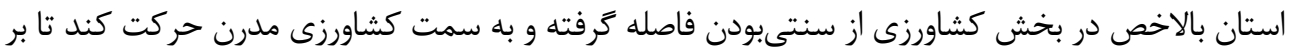

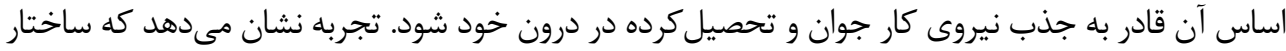

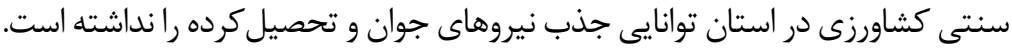

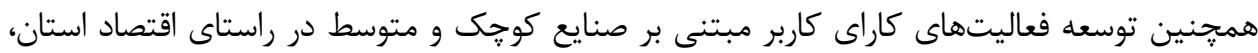

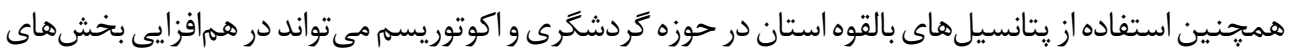

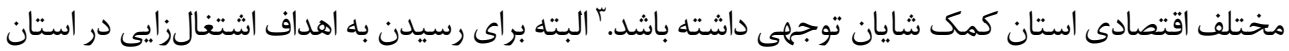

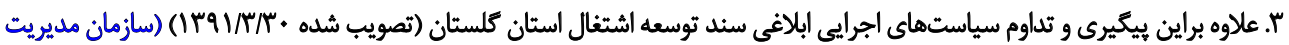

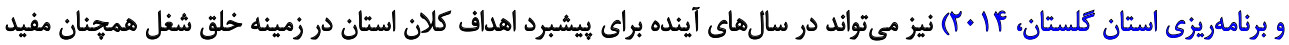

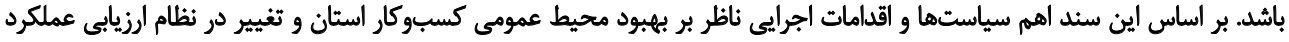


كلستان همجنان لازم است تا توجهى ويزه به رفع مهمرترين موانع و مشكلات شناسايى شده در اجراى اسناد

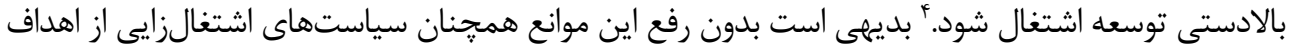
خود فاصله خواهند ترفت.

\section{ملاحظات اخلاقى}

\section{ييروى از اصول اخلاق يثروهش}

همه اصول اخلاقى در اين مقاله رعايت شده است. شركت كنند

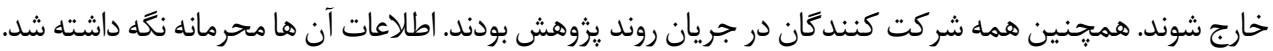

حامي مالى

اين يثوهش با استفاده از كمكهاى مالى معاونت يزوهشى دانشگاه كلستان در قالب طرح شماره انجام شده است.

مشاركت نويسندكان

با توجه به اينكه مقاله فقط يك نويسنده داشته است، تمامى بخشها و مراحل محصول كار يك نفر است و مفهوم مشار كت نويسند

$$
\text { تعارض منأقُ }
$$

بنا به اظهار نويسنده مقاله، اين يزوهش هيجزَّهن تعارض منافعى ندارد.

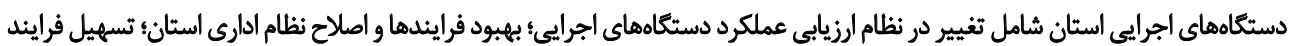

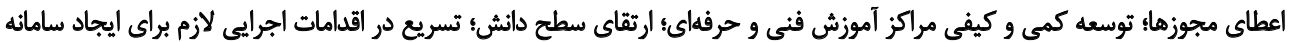

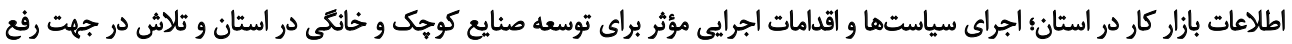

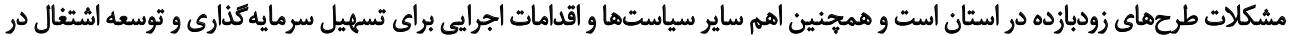

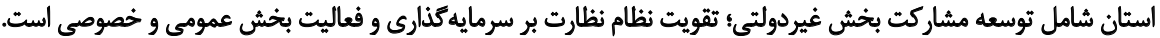

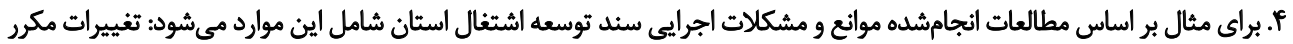

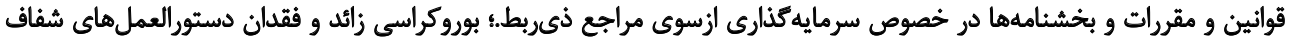

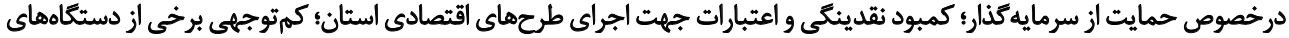

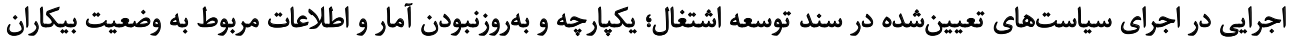

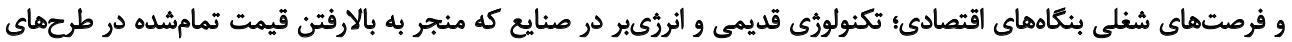

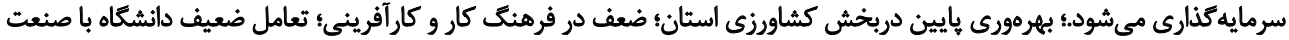

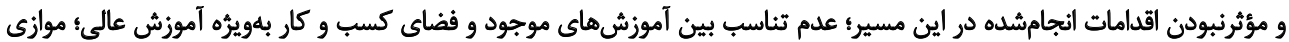

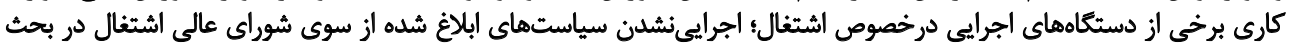

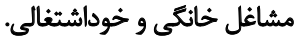




\section{References}

Al Abbasi, A. A., Shaha, S., \& Rahman, A. (2017). Employment and unemployment scenario of Bangladesh: A trends analysis. Journal of Economics and Sustainable Development, 8(2), 108-13.

Amini, A. R. (2015). [Analysis of labor market and employment policies of Iranian economy with emphasis on fourth plan of development, social and cultural (Persian)]. Economic Journal, 15(5-6), 23-40.

Amini, A. (2002). [Analyzing effective factors on economic sectors' labor demand and employment projections in the 3rd development plan (Persian)]. The Journal of Planning and Budgeting, 7(3), 53-86.

Baseri, B., \& Roshani Yasaghi, N. (2014). [Factors affecting on small industries jobs creation in Golestan province (Persian)]. Journal of Financial Economics, 8(26), 113-31.

D'Amuri, F., \& Marcucci, J. (2017). The predictive power of Google searches in forecasting US unemployment. International Journal of Forecasting, 33(4), 801-16. [DOI:10.1016/j.jiforecast.2017.03.004]

Gordon, T. J., \& Glenn, J. C. (1993). Issues in creating the millennium project: Report on phase i from the millennium project feasibility study. Washington, D.C.: United Nations University.

Hajiani, E., \& Ghassa, M. (2013). [Future, scenario writing and categorizing the methods and scenario (Persian)]. Socio-Cultural Research Journal of Rahbord, 2(8), 33-62.

Management and Planning Organization of Golestan Province. (2014). [Golestan province employment development document (Persian)]. Retrieved from: Not URL Link

Management and Planning Organization of Golestan Province. (2018). [Spatial planning studies of Golestan Province (Persian)]. Retrieved from: http:/golestanmporg.ir/amayesh-golestan.html

Nazmfar, H., Mohammadi, F., Zahedi Kalaki, I., \& Eshghi, A. (2016). [Spatial analysis and the level of classified city of Golestan based on employment indicators (Persian)]. Journal of Geography and Environmental Studies, 5(17), 7-20.

Sadi, M. R., \& Mousavi, M. H. (2013). [An investigation of factors and policies affecting labor force employment in Iranian economy (Persian)]. Journal of Economic Research, 13(49), 177-98.

Schanne, N., Wapler, R., \& Weyh, A. (2010). Regional unemployment forecasts with spatial interdependencies. International Journal of Forecasting, 26(4), 908-26. [DOI:10.1016/j.ijforecast.2009.07.002]

Statistical Centre of Iran. (2017). [Workforce statistics plan for years 2010-2017 (Persian)]. Retrieved from: https://bit.ly/2Q5df3r

Valciukas, J., \& Bell, W. (2017). Foundations of futures studies: Volume 1: History, purposes, and knowledge. Abingdon: Routledge.

Voros, J. (2003). A generic foresight process framework. Foresight, 5(3), 10-21. [DOI:10.1108/14636680310698379.] 
بيوست ا. ييشبينى نرخ بيكارى مردان استان تلستان، سناريوهاى ثقاضا و نرخ مشاركت بايه

\begin{tabular}{|c|c|c|c|c|c|c|c|c|c|c|}
\hline$f \cdot \theta$ & $1 f+f$ & $1 F+r$ & If.Y & $1 f \cdot 1$ & $11+$ & 1799 & img & irgy & imq & سيناريوهاي آينده \\
\hline TNY & $W / 1$ & $r \& / 1$ & $r \Delta / 1$ & $r \in M$ & $M / 1$ & $M / 9$ & $r \cdot 18$ & $19 / \pi$ & IV/a & سناريوى اول صفر ششل \\
\hline Tele & $r \Delta / V$ & $r F / \Lambda$ & $r f \%$ & $r / 1$ & $T r / T$ & $r M / 1$ & $r .1$. & WA & IV/F & سناريوى دوم ...1 شغل \\
\hline$r \Delta / 1$ & $r e / r$ & $\pi / \Delta$ & $r Y / A$ & $M / M$ & $r M / r$ & $r \cdot / f$ & $19 / 8$ & We & $I V / r$ & سناريوى سوم +..."T شغل \\
\hline $\mathrm{M} / \mathrm{s}$ & $M r / q$ & $r r / r$ & $r M / V$ & 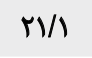 & $r \cdot / \Delta$ & $19 / 8$ & $W / A$ & $1 V / 9$ & $19 / 9$ & سناريوى جهارم •..." شعل \\
\hline$M / M$ & $r M / \Delta$ & $\mathrm{rI} /$ & $r+/ \Delta$ & $r . \%$ & $19 / 8$ & W/a & $W / r$ & IV/F & $18 / 8$ & سناريوى ينجم .... f شغل \\
\hline$r \cdot / 8$ & $r \cdot / r$ & $19 / V$ & $19 / 5$ & $19 /$. & WN & $|W|$ & IV/e & $\mathrm{IV} /$ & $\mid \varepsilon / \mu$ & سناريوى شُشم •... ش شغل \\
\hline $19 / 1$ & $W V$ & $W / F$ & WT & W. & $\mid V / A$ & $I V / \varphi$ & $\mid \mathrm{V} /$ & $\mid \% / \Delta$ & $1 \%$ & سناريوى هفتم ..." شغل \\
\hline$I V / \Delta$ & $\mid \mathrm{V} / \mathrm{m}$ & $I V / r$ & $\mid Y /$ & $|V|$ & $18 / 9$ & $18 / 8$ & $\mid E / F$ & $|\xi|$ & $1 \Delta / N$ & سناريوى هشتم •... شغل \\
\hline $\mid \varepsilon /$ & $10 / 9$ & $10 / 9$ & $1 \Delta / 9$ & $|q|$ & $|q|$ & $10 / 9$ & $10 / \Lambda$ & $\mid \omega / 8$ & $\mid \Delta / \mu$ & سناريوى نهم +.+م شغل \\
\hline $1 f / \Delta$ & $14 / 0$ & $\mid f / 8$ & $\mid f / A$ & $1 f / 9$ & $10 / 1$ & $10 / 1$ & $10 / 1$ & $|\Delta /|$ & $10 /$ & سناريوى دهم +.+.9 شغل \\
\hline $\mid r / *$ & $\mid w / 1$ & $\mid \pi / r$ & $1 \% / 8$ & $1 \% / 9$ & $1 F / r$ & $14 / F$ & $\mid f / \Delta$ & $I F / V$ & $I F / N$ & سناريوى يازدهم ه +. ا شغل \\
\hline
\end{tabular}

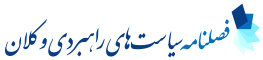

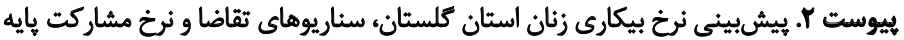

\begin{tabular}{|c|c|c|c|c|c|c|c|c|c|c|}
\hline $1 P+\Delta$ & $1 P \cdot p$ & $\mid r+r$ & If+r & $\mid f+1$ & $1 f_{++}$ & 1499 & Iस⿴囗十 & irar & irqs & سناريوهاي آينده \\
\hline$r \Delta / q$ & $r \Delta / f$ & $\mathrm{ra} /$. & $M \in / V$ & $m e / r$ & $m / 9$ & $m / \varphi$ & $m / \Lambda$ & $\pi / r$ & $m / \Delta$ & سناريوى اول صفر شُل \\
\hline$m / 1$ & $\pi / \Lambda$ & $M / \Delta$ & $\pi / \pi$ & M & $r r / q$ & $M / \Delta$ & $m / 1$ & $\mathrm{MIN}$ & m/l & سناريوى دوم ...1 شغل \\
\hline$M / T$ & $M T / r$ & $M / M$ & $M r /$. & $\mathrm{r} / \mathrm{a}$ & $m / / q$ & $M / V$ & $\mathrm{~m} / \mathrm{d}$ & $M / r$ & מ. & سناريوى سوم •..."r شغل \\
\hline$r+/ \Delta$ & $\mu \cdot / \Delta$ & $r \cdot / 8$ & $r+/ V$ & $\mu+/ \Lambda$ & $m+/ 9$ & $\mu+/ \Lambda$ & $\mu / / \Lambda$ & $r+/ s$ & $r \cdot / f$ & سناريوى جهارم +.."r شغل \\
\hline HNV & TNG & $r q /$ & $r q / 4$ & $r 9 / 8$ & $r 9 / 9$ & $\mu+/$ & $r \cdot / 1$ & $r+N$ & $r \cdot N$ & سناريوى ينجم +.+f شغل \\
\hline$r \& / q$ & $r V / r$ & rV/S & rN. & TND & YNG & $r q / 1$ & $r q / f$ & $r q / 8$ & $r q / N$ & سناريوى ششمر •... ه شغل \\
\hline$r \Delta / 1$ & $r \Delta / \&$ & $r g / 1$ & $r g / Y$ & $\mathrm{rV} / \mathrm{r}$ & YY/A & rNT & YNV & $r q /$ & $r q / F$ & سناريوى هفتم +..9 شغل \\
\hline$m / f$ & 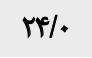 & $r e / N$ & $r \Delta / F^{e}$ & $r q / 1$ & $r \& / A$ & $r V / \Delta$ & TN. & TNG & $r q$. & سناريوى هشتم ... Vشغل \\
\hline TI/S & $\pi / T$ & $\pi / T$ & $\mathrm{re/l}$ & $r \Delta / \cdot$ & $r \Delta / \Lambda$ & TE/8 & $M V / T^{e}$ & WN & TNV & سثاريوى نهم .... A شغل \\
\hline $19 / 1$ & $r \cdot / N$ & $r M / N$ & $r / \mathrm{T}$ & $r / A$ & $r f / A$ & $r \Delta / \wedge$ & $r E / V$ & tVIF & rN/ & سناريوى دهم ...9 شغل \\
\hline W. & $19 / 1$ & $r+/ r$ & $r / / F$ & $M T / 8$ & $r M / \Lambda$ & $M r / q$ & $r \& /$. & $\mathrm{rV} /$. & rN. & سناريوى يازدهم ..... أشغل \\
\hline
\end{tabular}

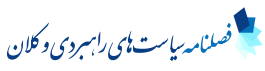


بيوست r. بيشبينى نرخ بيكارى استان تكلستان، سناريوهاى تثاضا ونرخ مشاركت يايه

\begin{tabular}{|c|c|c|c|c|c|c|c|c|c|c|}
\hline $1 f+\Delta$ & $1 f+f$ & $1 F+r$ & $\mid F+r$ & $|f+|$ & if.. & 1т99 & Irq & Irqy & irge & سناريوهاي آينده \\
\hline$r q / \Delta$ & TNE & $T V / V$ & re/A & $r \Delta / 9$ & $r \Delta / 1$ & $r \%$ & $T M / 9$ & $T / N$ & $r \cdot / f$ & سناريوى اول صفر شغل \\
\hline$r V / a$ & 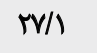 & $r \varepsilon / r^{e}$ & $r \Delta / \&$ & $r e / q$ & me/ & $r / r$ & $M T / K$ & $r M / r$ & $r \cdot / l$ & سناريوى دوم .... ششغل \\
\hline$r e / f$ & $r \Delta / \mathrm{V}$ & $r \Delta / 1$ & $M F / 0$ & $r \pi / q$ & $M / T$ & $M / \Delta$ & TI/S & $r \cdot N$ & $19 / N$ & سناريوى سوم .... H شغل \\
\hline$r F / \Lambda$ & $M \varphi / \mu$ & $\pi / N$ & $\pi / \pi$ & $\pi / \Lambda$ & 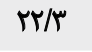 & $M / r$ & $M I /$. & $r \cdot / r$ & $19 / 9$ & سناريوى جهارم •..." شغل \\
\hline$\pi / r$ & $M / A$ & $M / P$ & $M / M$ & $r / \Lambda$ & $M / F$ & $r . / 9$ & $r \cdot / \varphi$ & $19 / 1$ & $19 / 1$ & سناريوى ينجم .... Pُشغل \\
\hline rIV & $r M / P$ & M/I & $r+/ q$ & $r \cdot N$ & $r \cdot / \Delta$ & $r \cdot / 1$ & $19 / 1$ & $19 / \pi$ & $W / \Lambda$ & سناريوى ششم .... ش شغل \\
\hline$r+M$ & $19 / 9$ & $19 / 1$ & $19 / \mathrm{V}$ & $19 / V$ & $19 / 8$ & $19 / 5$ & $19 / 1$ & $W / A$ & Wo & سناريوى هفتم +.." ششل \\
\hline WE & WD & $W \Delta$ & WD & WE & WV & WE & WD & $W /$ & $W /$ & سناريوى هشتم ل... Vشغل \\
\hline $\mid \mathrm{V} / *$ & $\mid V / *$ & $I V / \pi$ & IV/F & IV/S & IV/A & $\mid V / \Lambda$ & $18 / 9$ & $18 / 9$ & $\mid V / \Lambda$ & سناريوى نهم +... ش شغل \\
\hline $1 \Delta / \%$ & $10 / 8$ & $10 / 9$ & $18 / \pi$ & $1 \% / \Delta$ & $19 / 9$ & $|V /|$ & $\mid V / N$ & $\mid V / F$ & $I V / \Delta$ & سناريوى دهم +.+? شغل \\
\hline $1 \% / 9$ & $1 F / \pi$ & $1 F / \Delta$ & $\mid \Delta /$ & $10 / \Delta$ & 191. & $18 / \pi$ & $\mid \& / 8$ & $19 / 9$ & $I V / r$ & سناريوى يازدهم •.... شغل \\
\hline
\end{tabular}
|ct

بيوست F. بيشبينى نرخ بيكارى مردان استان كلستانه سئريوهاى تقاضا و افزايش . ال درصد مشاركت

\begin{tabular}{|c|c|c|c|c|c|c|c|c|c|c|}
\hline $1 f+\Delta$ & $i f+f$ & iftr & If+r & $\mid f+1$ & If + . & 1799 & ira & irar & 1rag & سناريوهاى آينده \\
\hline$m e / V$ & $M / N$ & $M T / \Lambda$ & $m / q$ & $\mathrm{~m} / \cdot$ & 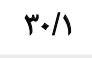 & rq. & $r V / a$ & rele & $r \Delta / r$ & سناريوى اول صفر شغل \\
\hline$M / \pi$ & $M T / \Delta$ & MIN & $r \cdot / q$ & $r+/$ & $r q / r$ & KNT & $T V / r$ & $r e / T$ & $r \Delta / \cdot$ & سناريوى دوم •... ششل \\
\hline 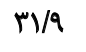 & $M / T$ & $r \cdot / \Delta$ & $r q / \Lambda$ & $r q / \pi$ & TND & TV/S & $r \in / N$ & $r \Delta / \Lambda$ & $r \varphi / \Lambda$ & سناريوى سوم •..." شغل \\
\hline$r+18$ & $r 9 / 9$ & $r q / \mu$ & TNA & TN/T & $r V / V$ & $\mathrm{rV} / *$ & $r e / T$ & $r \Delta / f$ & $M E / \Delta$ & سناريوى جهارم +.+"r شغل \\
\hline$r q / r$ & YNV & TN/T & $r V / N$ & $r Y /{ }^{\prime \prime}$ & $r \varepsilon / 9$ & $r \& / r$ & $r \Delta / 8$ & $r e / q$ & $\pi / r$ & سناريوى ينجم +..+ ش شغل \\
\hline$r Y / A$ & $\mathrm{rV} / \mathrm{C}$ & $\mathrm{rV} /$ & $r E / N$ & $r g / f$ & $r \& / 1$ & $r \Delta / 9$ & $r \Delta / 1$ & $M F / \Delta$ & $r m / q$ & سناريوى ششه ...0. شغل \\
\hline$r E / r$ & $r g / l$ & $r \Delta / \Lambda$ & $r \Delta / 8$ & $r \Delta / \Delta$ & $r \Delta / T^{\prime}$ & $M y / q$ & $M r / \Delta$ & $M F / \Lambda$ & $r / s$ & سناريوى هفتم +.." شغل \\
\hline$r \Delta / \cdot$ & 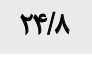 & $r f / N$ & $\mathrm{re} / \mathrm{s}$ & $r e / \Delta$ & $M F / \Delta$ & $m / r$ & $\pi \%$ & $\pi / N$ & $\pi / r$ & سناريوى هشتم V... ششغل \\
\hline$\pi / R$ & $M / Q$ & $\pi / \Delta$ & $M / \Delta$ & $M T / 8$ & $\pi / Y$ & $r r / \Delta$ & $M / T^{\circ}$ & $\pi / \pi$ & $\pi /$ & سناريوى نهم .... شغل \\
\hline$r / \pi$ & $r / T$ & $M T / R$ & $M r / \Delta$ & $r T / Y$ & $r / A$ & $r r / q$ & $r / 9$ & $r / \Lambda$ & $r / \Lambda$ & سناريوى دهم ....9 شغل \\
\hline$r \cdot / q$ & $r /$. & $r M / r$ & MV/ & $M / N$ & $\mathrm{rr} /$. & $T r / T$ & $\pi / r$ & $r T / F$ & $r M / \Delta$ & سناريوى يازدهم +.... أشل \\
\hline
\end{tabular}

(1) 


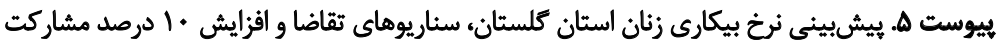

\begin{tabular}{|c|c|c|c|c|c|c|c|c|c|c|}
\hline $1 f \cdot \Delta$ & $1 f+f$ & $\mid f+r$ & If.Y & $|f|$ & $1 f+$ & 1799 & irqu & irgy & irqs & سناريوهاي آينده \\
\hline$P I / N$ & 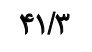 & $f \cdot / 9$ & $P \cdot 18$ & $r+/ r$ & $\mathrm{rq/9}$ & $r q / p^{c}$ & rNa & rNe & $\mathrm{W} / \mathrm{V}$ & سناريوى اول صفر شُل \\
\hline$P \circ / 1$ & $\mathrm{rq} / \mathrm{A}$ & mqg & $r q / f$ & $r q / r$ & $\mathrm{rq} /$ & HNV & rNM & $r v / q$ & $\mathrm{~W} / \mathrm{e}$ & سناريوى دوم .... شعل \\
\hline HNF & rNT & rNT & TNT & $r N$ & rN & $m / q$ & $\mathrm{~W} / \mathrm{V}$ & $\mathrm{m} / \mathrm{e}$ & $m / 1$ & سناريوى سوم •...r شغل \\
\hline $\mathrm{mg/A}$ & re/A & $r g / 9$ & $\mathrm{~m} /$ & $r v / 1$ & $\mathrm{rV} /$ & $\mathrm{m} / 1$ & $\mathrm{~m} / \mathrm{I}$ & $m e / q$ & $r E / V$ & سناريوى جهارم ...." شغل \\
\hline$r \Delta / r$ & $r \Delta / \%$ & $\mathrm{ral} / \mathrm{s}$ & $r \Delta / \Lambda$ & rel. & $r g / K$ & $r g / \varphi$ & re/f & $r g / \Delta$ & $r g / f$ & سناريوى ينجم ... f شغل \\
\hline$M / 8$ & $m / q$ & $M \varphi / r$ & $m / s$ & $r \Delta / \cdot$ & $r \Delta / r$ & $r \Delta / 8$ & $r \Delta / 1$ & ए\%l. & re/l & سناريوى شُشم ..."ه شغل \\
\hline$r / 9$ & $M T / P$ & $M / q$ & $\pi / 4$ & $\pi / 9$ & $m \varphi / \varphi$ & $m e / \Lambda$ & $r \Delta / r$ & $r \Delta / \Delta$ & $r \Delta / \Lambda$ & سناريوى هفتم ..." شغل \\
\hline$r \cdot r$ & $r \cdot / 9$ & $M / \Delta$ & $M / T$ & $r T / \Lambda$ & $\pi / \Delta$ & $m / 1$ & $m \in / 8$ & $r \Delta / 1$ & $r \Delta / \Delta$ & سناريوى هشتم +.." شغل \\
\hline YNV & $r q / 4$ & $r+/ r$ & $\mathrm{~m} / \cdot$ & $\mathrm{r} / \mathrm{A}$ & $M T / S$ & $\pi / r$ & $m \varphi /$ & 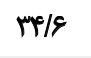 & $r \Delta / r$ & سناريوى نهم +.+م شغل \\
\hline YV/I & $\mathrm{TV} / \mathrm{q}$ & rNA & $r q / \lambda$ & $r+/ r$ & $M / V$ & $r T / \Delta$ & $\pi / 4$ & $m / 1$ & $m / 1 /$ & سناريوى دهم +++9 شغل \\
\hline$r \Delta / \kappa^{\circ}$ & $r \varepsilon / F$ & $r V / \Delta$ & TNE & $r q / V$ & $r+/ \Lambda$ & $r \mid / \wedge$ & $m / V$ & $M / V$ & $m / \Delta$ & سناريوى يازدهم + +. ا شغل \\
\hline
\end{tabular}
|ct

هييوست و. ييشبينى نرخ بيكارى استان كلستان سناريوهاى تقاضا و افزايش • أدرصد مشاركت

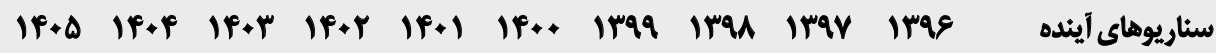
سناريوى اول صفر شغل سناريوى دوم .... شغل سناريوى سوم •..r.

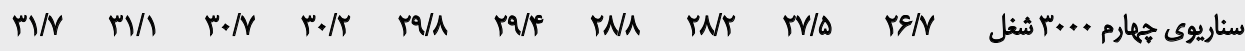
سناريوى ينجم +.+4

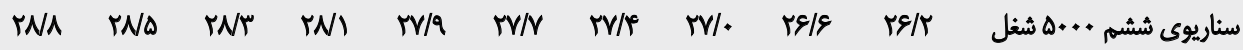
سناريوى هفتم +..

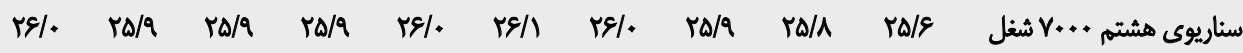

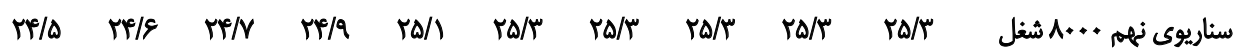
سناريوى دهم ...

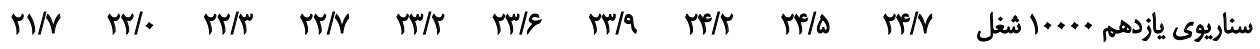
(2) 
هييوست V. ييشبينى نرخ بيكارى مردان استان كلستان، سناريوهاى ثقاضا و كاهش · ل درصد مشاركت

\begin{tabular}{|c|c|c|c|c|c|c|c|c|c|c|}
\hline$I f+\Delta$ & If $+f$ & If.r & $1 f+r$ & $1 f \cdot 1$ & If.. & 1199 & 1691 & Irav & Irqs & سناريوهاي آينده \\
\hline$r \cdot / r$ & $19 /$. & $1 V / 9$ & $18 / 1$ & $1 \Delta / N$ & $18 / 8$ & $1 \pi / \pi$ & $11 / 4$ & $1 . / r$ & NV & سناريوى اول صفر شثل \\
\hline WA & $I V / \Delta$ & $19 / 0$ & $10 / \Delta$ & $\mid f / 8$ & $1 \% / 8$ & $\mid r / 4$ & $11 / 1$ & V/^ & Ne & سناريوى دوم .... شغل \\
\hline $18 / 1$ & $10 / 9$ & $10 / 1$ & $I f / r$ & $\mid r / f$ & $\mid r / 8$ & $11 / 8$ & 1.10 & $9 / r$ & $N \cdot$ & سناريوى سوم ..... شغظل \\
\hline $\mid Q / 1$ & $1 \% / \%$ & $1 w / 9$ & $1 \mathrm{~m} /$ & $\mid r / r$ & $11 / 8$ & $1 . / N$ & $9 / 1$ & $N A$ & $\mathrm{~V} / \mathrm{V}$ & سناريوى جهارم •..." شغل \\
\hline $1 \pi / f$ & $\mid r / A$ & $I T / r$ & $11 / N$ & $11 / r$ & 1.18 & $9 / 9$ & $9 / 1$ & $N r$ & $V / r$ & سناريوى ينجم ... f شُشل \\
\hline $11 / V$ & $11 / r$ & $1 . / 1$ & $1 . / 4$ & $1 . \%$ & $9 / 8$ & $9 / 1$ & $N F^{\circ}$ & $V / \wedge$ & $\mathrm{V} /$ & سناريوى ششم ...0ه شغل \\
\hline $1 . / 1$ & $9 / /$ & $9 / 4$ & १/ & Nq & $N V$ & $N / T$ & $V / \Lambda$ & $V / r$ & sis & سناريوى هفتم ....8 شغل \\
\hline $\mathcal{N} F$ & $N$ & $N$ & $V / A$ & $V / A$ & $V / V$ & $V / F$ & V/I & $s / N$ & $e / \mu$ & سناريوى هشتم ... Vشغل \\
\hline$s / V$ & $9 / 8$ & $9 / \Delta$ & $9 / 8$ & $8 / \&$ & $s / V$ & $9 / 8$ & $g / f$ & $g / r$ & $\Delta / 9$ & سناريوى نهم +.+. ش شغل \\
\hline$\Delta / *$ & $\Delta /$ & $\Delta / 1$ & $\Delta / \Gamma^{\top}$ & $\Delta / \Delta$ & $\Delta / V$ & $\Delta / V$ & $\Delta / V$ & $\Delta / V$ & $\Delta / 8$ & سناريوى دهم +..9 شغل \\
\hline$r / r$ & $r / \Delta$ & $r / N$ & $4 \%$ & $t / F$ & $F / V$ & $4 / q$ & $\Delta / \bullet$ & $\Delta / r$ & $\Delta / r$ & سناريوى يازدهم ...... شغل \\
\hline
\end{tabular}

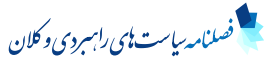

هيوست A. ييشبينى نرخ بيكارى زنان استان كلستان، سناريوهاى تقاضا و كاهش • ا درصد مشاركت

\begin{tabular}{|c|c|c|c|c|c|c|c|c|c|c|}
\hline$I f+\Delta$ & iftf & If+r & $1 f+r$ & $\mid f+1$ & $1 f+$ & 1799 & irqu & irar & iras & سناريوهاى آينده \\
\hline TNY & $r N T^{2}$ & $r V / \Lambda$ & $r V / F$ & $\mathrm{rV} /$. & $r / \Delta$ & $r \%$ & $r \Delta / r$ & $r \varphi / N$ & $M / \Lambda$ & سناريوى اول صفر شغل \\
\hline$r E / V$ & $r \& / 4$ & TE/T & $r \Delta / q$ & $r \Delta / Y$ & $r \Delta / F^{\prime}$ & $r \Delta /$. & $m / \varepsilon$ & $M q / /$ & $\pi / \Delta$ & سناريوى دوم ...ا شغل \\
\hline$m+1 /$ & ry/E & $m / \Delta$ & $\mathrm{rr/ \Delta}$ & $r f / 4$ & $m$ & $r+/$ & $r / \Lambda$ & $M / \Delta$ & 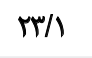 & سناريوى سوم •..+r شغل \\
\hline$r T / \Lambda$ & $r r / A$ & $M T / q$ & $\mathrm{~m} /$ & $r r / l$ & $r / T$ & $r r / r$ & M & $r r / q$ & $r T / Y$ & سناريوى جهارم +++"r شغل \\
\hline$r+/ \Lambda$ & $\mathrm{rI} / \mathrm{H}$ & $r / T$ & rI/D & $M / A$ & $r / /$ & $r T / 4$ & $r r / r$ & $r T / 4$ & $r r / r$ & سناريوى ينجم +... ش شغل \\
\hline WA & $19 / r$ & $19 / 8$ & $r . /$. & $r \cdot / \Delta$ & $r+/ q$ & $r M / r$ & rI/S & $r / \wedge$ & $r M / 9$ & سناريوى ششم •...0 شغل \\
\hline $18 / \lambda$ & $\mid V / F$ & $1 V / 9$ & WE & $19 / r$ & $19 / 1$ & $r+/ r$ & $r+1 /$ & $r M / r$ & $r M / \Delta$ & سناريوى هفتم ... شعغل \\
\hline $1 F / A$ & $1 Q / \Delta$ & $\mid \& / \mu$ & $|V /|$ & $1 V / 9$ & WV & $19 / f^{\circ}$ & $r \cdot / 1$ & $r \cdot 18$ & $M / /$ & سناريوى هشتم V... شثفل \\
\hline $1 T / 9$ & $\mathbb{M} / V$ & $\mid f / 8$ & $10 / 8$ & 1818 & $\mid V / 8$ & WD & $19 / r$ & $r \cdot / 1$ & $r \cdot / \Lambda$ & سناريوى نهم ... A شغل \\
\hline $1 . / 9$ & $11 / 9$ & $1 \% \%$ & 1 & $1 \Delta / r$ & $\Delta$ & $\mathrm{IV} / \mathrm{Q}$ & Wo & $19 / \Delta$ & $r \cdot / f$ & سناريوى دهم ....9 شغل \\
\hline N/9 & $1 . / 1$ & $11 / 6$ & $\mathbb{H} / N$ & $\mid f /$ & $10 / 5$ & 1918 & IV/A & $W / q$ & $r . \%$ & سناريوى يازدهم +.... شغل \\
\hline
\end{tabular}

(2) 
بيوست 9. بيشبينى نرخ بيكارى استان كُلستان، سناريوهاى ثقاضا و كاهش • ا درصد مشاركت

\begin{tabular}{|c|c|c|c|c|c|c|c|c|c|c|}
\hline$I f+\Delta$ & $1 f+f$ & If+r & If.r & $\mid f+1$ & if.. & 1т99 & irqu & irgv & imq9 & سناريوهاي آينده \\
\hline$M / N$ & $r \cdot 18$ & $19 / V$ & $W V$ & IV/V & $18 / N$ & $1 Q / \Delta$ & $\mid F / \pi$ & $1 \%$ & $11 / \Delta$ & سناريوى اول صفر شغل \\
\hline 19/9 & $19 /$ & Wr & $I V / F$ & $18 / 8$ & $10 / V$ & $1 F / V$ & $1 \% / 8$ & $1 \% / F$ & $11 / r$ & سناريوى دوم .... شعل \\
\hline Wr & $\mid V / f$ & $1 \notin / N$ & $18 /$ & $1 \Delta / f^{e}$ & $1 f / N$ & $1 r / \lambda$ & $1 \% / 9$ & $11 / 9$ & $1 . / 1$ & سناريوى سوم ..... شغل \\
\hline $18 / 0$ & $10 / \Lambda$ & $18 / r$ & If $/ V$ & $19 / \pi$ & $i w / V$ & $1 \% \%$ & $I r / r$ & $11 / \%$ & $1 . / \Delta$ & سناريوى جهارم ...." شغل \\
\hline $19 / N$ & $I F / r$ & $1 w / \lambda$ & $1 \% / F$ & $1 m / 1$ & $I T / N$ & $\mid r / 1$ & $W / \Delta$ & $1 . / 9$ & $1 . / 1$ & سناريوى ينجم .... H شغل \\
\hline $1 \% \%$ & $1 \% / 8$ & $\mathbb{I r / F}$ & $M / 1$ & $11 / 9$ & $11 / V$ & $11 / r$ & 1.11 & $1 . / r$ & $9 / \wedge$ & سناريوى شُشم ..." شغل \\
\hline $11 / r$ & $11 /$ & $1 . / 9$ & 1.11 & $1 . / V$ & $1 \cdot N$ & $1 . / 4$ & $1 . / 1$ & $\sqrt[q]{ } / 1$ & $9 / 4$ & سناريوى هفتم ..." شغل \\
\hline $9 / \Delta$ & $9 / 4$ & $9 / 8$ & $q / \Delta$ & $9 / 8$ & $9 / V$ & १/ร & $9 / \Delta$ & $q / r$ & १/. & سناريوى هشتم ... W شغل \\
\hline$V / \lambda$ & $V / \lambda$ & $N$ & NT & $N T^{\leftarrow}$ & $N N$ & $\mathcal{N N}$ & $N /$ & $N \wedge$ & $\mathcal{N} V$ & سناريوى نهم ++"م شغل \\
\hline 91. & $8 / r$ & $g / \Delta$ & $8 / 9$ & $v / r$ & $\mathrm{~V} / \mathrm{e}$ & $V / 9$ & $N$ & $N T$ & $\mathcal{N}{ }^{r}$ & سناريوى دهم ++.+9 شغل \\
\hline$r / \mu$ & $r / 8$ & $\Delta / 1$ & $\Delta / 8$ & $8 / 1$ & $8 / 8$ & $\mathrm{~V} /$. & $V / f$ & $V / V$ & $N \cdot$ & سناريوى يازدهم •.... ا شغل \\
\hline
\end{tabular}

